University of Louisville

ThinkIR: The University of Louisville's Institutional Repository

Electronic Theses and Dissertations

8-2017

\title{
Advances in tumor-targeted therapy using nanomedicine.
}

Divya Karukonda

University of Louisville

Follow this and additional works at: https://ir.library.louisville.edu/etd

Part of the Pharmacology, Toxicology and Environmental Health Commons

\section{Recommended Citation}

Karukonda, Divya, "Advances in tumor-targeted therapy using nanomedicine." (2017). Electronic Theses and Dissertations. Paper 2800.

https://doi.org/10.18297/etd/2800

This Master's Thesis is brought to you for free and open access by ThinkIR: The University of Louisville's Institutional Repository. It has been accepted for inclusion in Electronic Theses and Dissertations by an authorized administrator of ThinkIR: The University of Louisville's Institutional Repository. This title appears here courtesy of the author, who has retained all other copyrights. For more information, please contact thinkir@louisville.edu. 


\title{
ADVANCES IN TUMOR-TARGETED THERAPY USING NANOMEDICINE
}

\author{
By \\ Divya Karukonda \\ M.S., Pharmaceutical sciences
}

A Thesis Submitted to the Faculty of the School of Medicine of the University of Louisville in Partial Fulfillment of the Requirements for the Degree of

\author{
Master of Science \\ in Pharmacology and Toxicology
}

Department of Pharmacology \& Toxicology

University of Louisville

Louisville, KY

August 2017 



\title{
ADVANCES IN TUMOR-TARGETED THERAPY USING NANOMEDICINE
}

\author{
By \\ Divya Karukonda \\ M.S., Pharmaceutical sciences
}

A Thesis Approved on

July 31st, 2017

By the following Thesis Committee

Ramesh Gupta, Ph.D.

Jun Yan, Ph.D.

Carolyn M. Klinge, Ph.D.

Radha Munagala, Ph.D. 


\section{DEDICATION}

This thesis is dedicated to my beloved husband, my sweet son and to my parents for their continuous support, encouragement and love. 


\section{ACKNOWLEDGEMENTS}

It is my pleasure to express my gratitude to my mentor Dr. Ramesh Gupta for his unwavering support, patience, guidance, and encouragement. His true passion for science and unflinching work ethic commitment has inspired me in developing as a person going forward. I would also like to thank my committee members Dr. Jun Yan, Dr. Carolyn Klinge and Dr. Radha Munagala for their comments and assistance. I express my special thanks to Dr. Radha Munagala and Dr. Ashish Agarwal for their valuable suggestions and assistance during the preparation of this thesis. I would also like to thank my lab members $-\mathrm{Dr}$. Farrukh Aqil, Jeyaprakash Jeyabalan, Al Hassan Kyakulaga and Ashley Marie Mudd for their continuous support during the course of my laboratory work. 


\begin{abstract}
ADVANCES IN TUMOR-TARGETED THERAPY USING NANOMEDICINE
\end{abstract}

Divya Karukonda

July 31 st, 2017

Despite continuous improvement and significant progress made in diagnostic and therapeutic approaches for cancer, it is still the leading cause of death worldwide. Although conventional chemotherapy has made significant advances in improving patient survival the indiscriminate destruction of normal cells leads to severe side effects and poor clinical outcomes. Thus, there is a need for effective delivery of drugs to the tumor site avoiding normal tissues to reduce toxicity in the rest of the body. For this reason, a novel multidisciplinary field called Nanotechnology has evolved in recent years and advances in this field have contributed to the development of nanoscale materials to overcome the lack of specificity of conventional chemotherapeutic agents for optimized cancer therapy. Nanoparticles can be designed to preferentially target the tumor site and deliver high drug payloads by either passive or active targeting. Passive targeting exploits the preferential drug accumulation in tumor cells through enhanced permeability and retention (EPR) effect. On the other hand, active 
targeting uses functionalized nanoparticles to carry a drug to the specific site. This targeting strategy is becoming a new standard in cancer treatment. A selective and tumor site-specific treatment can be achieved by using various ligands such as aptamers, antibodies, peptides, and small molecules. Targeting nanocarriers serve as a highly promising strategy for effective cancer treatment, as shown by encouraging results in many recent studies. This thesis highlights the diversity of nanoparticle types, targeting mechanisms and active targeting strategies. I will also discuss an emerging field of nano drug delivery using biological nanovesicles called exosomes. Finally, I will discuss the current clinical status of nanoparticle formulations. 


\section{TABLE OF CONTENTS}

\section{PAGE}

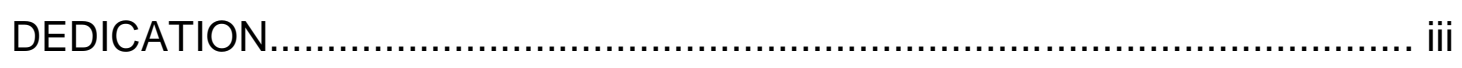

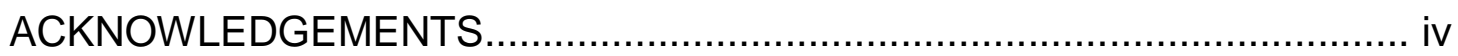

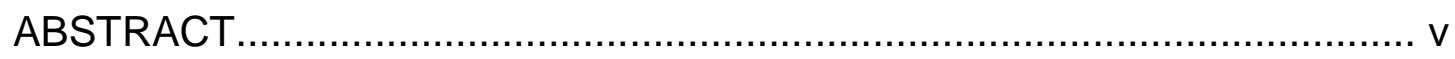

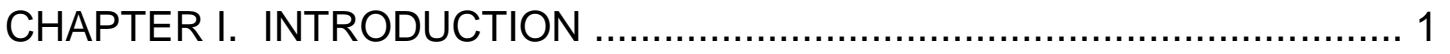

CHAPTER II. DRUG TARGETING MECHANISMS ...............................11

CHAPTERIII. LIGANDS FOR TARGETING $\ldots \ldots \ldots \ldots \ldots \ldots \ldots \ldots \ldots \ldots \ldots \ldots \ldots \ldots \ldots$

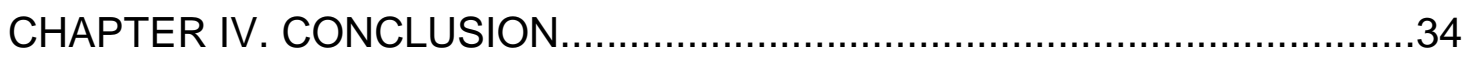

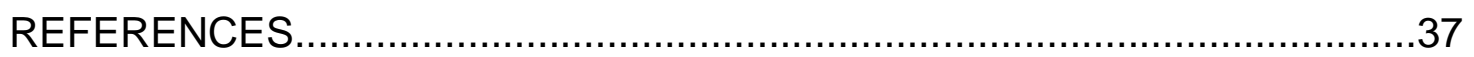

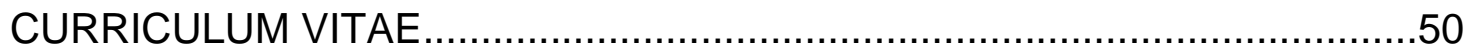




\section{CHAPTER I}

\section{INTRODUCTION}

Cancer and therapy

Cancer is the leading cause of death worldwide despite continuous improvement in the therapeutic strategies and early detection. Cancer incidence has been increasing in recent decades and American Cancer Society estimates that the number of new cases are projected to increase by $50 \%$ worldwide from 14 million in 2012 to 22 million by 2030. In 2017, 1,688,780 new cancer cases and 600,920 cancer deaths are estimated to occur in the United States (1). Cancer is a complex disease caused by uncontrolled growth and division of abnormal cells due to gene mutations. As a result of mutational changes, cancer cells exhibit certain characteristics including proliferation, resistance to signals that inhibit their growth and resistance to apoptotic signals that cause cell death, which make it difficult to treat the disease (2). Cancer cells interact with the microenvironment to acquire different capabilities during the multistep development of a tumor particularly, overcome immune response for survival, activate stromal cells to inappropriately promote angiogenesis, and invade through tissues, and metastasize to distant organs induced by tumor microenvironment components (3). 
Standard treatment for cancer includes combinations of surgery, radiation and chemotherapy (chemo). Other treatment options include hormonal therapy and targeted therapy (including immunotherapy such as monoclonal antibody therapy). The choice of therapy depends upon the location, grade of the tumor and the stage of the disease. Over the last decade a number of potent anticancer drugs have been developed with various mechanisms of action such as blocking nucleic acid biosynthesis, interfering with gene transcription, causing cell cycle arrest, inducing apoptosis, and inhibiting angiogenesis (4).

Limitations of conventional therapy

Conventional chemotherapy that targets DNA is very effective and has resulted in improved survival rates of cancer patients. However, it has several limitations such as poor solubility, poor selectivity, non-specific drug distribution, fast clearance rate, systemic toxicity, multi-drug resistance, cancer reoccurrence, off- target effects along with severe side effects (5). These limitations pose a significant challenge in the effective treatment of cancer. Most of the chemotherapeutics in the market at present such as doxorubicin, paclitaxel, and vincristine have less selectivity toward the target and are systemically distributed without selective localization to site of tumor. Thus, higher doses are required to achieve pharmacological levels at the target site and this leads to increased toxicity to the normal tissues causing severe side effects. An example of this is anthracycline drug causing cardiotoxicity, severe in some cases (6). In order to avoid toxic side effects, chemo drugs are often given at lower doses, which are 
less than the required doses resulting in subsequent failure of therapy accompanied by development of drug resistance and metastatic disease.

Hence, eradication of cancer still remains a major problem due to its heterogeneous nature and inability of chemotherapeutics to reach the tumor site without damaging the normal healthy tissues.

Effective solution

Delivering drug to the disease site is a major hurdle for many of the diseases including cancer. Because of the limitations noted above there has been enormous interest in developing an innovative technologies that can deliver drug at the target site. Over a century ago Paul Ehrlich introduced a concept of "Magic Bullet" for targeted drug delivery (7). It has two entities: the first one is that the drug should recognize the target and the second is that the drug should provide therapeutic action at the targeted site. Cell- or tissue-specific targeting is achieved by encapsulating a drug and targeting moiety in an appropriate pharmaceutical carrier which is the revised version of Ehrlich magic bullet (8). Nanoparticles can be designed including all three entities and could be used as both therapeutics and diagnostics. A number of studies show that most of the limitations of conventional drugs can be overcome by nanotechnology and that nanoparticles as carriers have huge potential to overcome the limitations of chemotherapeutics $(9,10)$. 
Nanotechnology in cancer

Nanotechnology involves use of nanometer scale materials and systems by controlling the matter on a level of atomic, molecular and supramolecular scale. (11-14). The size of nanomaterials is around $10-100 \mathrm{~nm}$ and their unique size is ideal for increased solubility, oral bioavailability, rate of dissolution, surface area, high therapeutic loading and rapid onset of therapeutic action upon intracellular uptake (15). In contrast, conventional drugs are rapidly cleared from the body, reducing the amount of drug at the tumor site (16). Nanocarriers with drugs incorporated increase the half-life of drugs in circulation, allowing a greater amount of drug to reach the target site (11). Anticancer drugs in nano formulations exhibit enhanced therapeutic index due to improved pharmacokinetics, tissue distribution, and enhanced accumulation or release of the drug at the tumor site (17). The nano-sized particles exhibit more extravasation and permeability into tumor tissues with leaky vasculature in contrast to neo-vasculature of normal tissues, minimizing off-target toxicities, and enhancing delivery to site of action. Their small size also facilitates oral, nasal, ocular, and parenteral routes of drug administration. Thus, nanoparticle drug delivery systems can serve as the successful tools to anticancer therapy.

A variety of nanostructures have been investigated such as synthetic biodegradable polymers, lipids (liposomes), mesoporous silica nanoparticles (MSNs), micelles, quantum dots, carbon nanotubes, and gold nanoparticles for the treatment of cancer (18-22). A summary of their properties is presented in Table (1) (23) 
Liposomes, first discovered by Dr. Alec Bangham in 1961 (24), and are extensively explored as the nanocarriers for the targeted drug delivery. A separate field of liposomal technology research was started by the approval of first nano drug - Doxil ${ }^{R}$ which is a big hit in the market. The field of liposomal literature is only focused on liposomes without the term nano until 2000 . Liposomes are closed vesicles surrounded by a lipid bi-layer membrane composed of phospholipids. Their hydrophilic core can be used for the entrapment and delivery of water-soluble drugs. These vesicles are uni- or mutilamellar and have a potential to carry both hydrophilic and lipophilic molecules entrapped within the lipid bilayer. Availability of liposomes with diverse properties makes them the most intelligent drug carrier systems available (25)

Polymeric micelles are nano-sized vectors that contain amphiphilic block copolymers which assemble to form nanoscopic core-shelled colloidal structures termed micelles. Their advantage is in trapping drugs physically within the hydrophobic cores or linking drugs covalently to component molecules of the micelle. Additionally, they proved to be an excellent novel drug delivery system due to their high stability in physiological conditions, high loading capacity, and high accumulation of drug at target site (26).

Dendrimers are a class of polymeric materials. First discovered in the early 1980's by Donald Tomalia and colleagues (27), these hyper-branched, tree-like, structured polymeric molecules originate from the Greek word dendron, meaning a tree. As the chains growing from the core molecule become longer and more branched, they adopt a globular structure. Dendrimers become 
densely packed as they extend out to the periphery, forming a closed membranelike structure. Their sizes range between $1.9 \mathrm{~nm}$ and $4.4 \mathrm{~nm}$, the smallest nancoarriers so far developed. Dendrimer-drug interactions or drug loading in dendrimers may be achieved by various approaches: simple encapsulation in the interior of dendrimers (illustrated in Fig. 1) involves electrostatic interactions and covalent conjugations to the surface of the dendrimers. They serve as an ideal carrier for drug delivery due to several advantages, for example, they can be modulated for target-specific drug delivery, have a defined molecular weight, are of a small size, and have good entrapment efficiency, thus offering a good surface for functionalization (28).

The general term nanoparticles (NPs), describes a wide range of nano systems including organic polymeric NPs, composed of synthetic or natural polymers or proteins (i.e, albumin), solid lipid nanoparticles comprising of physiological lipids, as well as inorganic NPs such as semiconductor NPs, iron oxide NPs, quantum dots and gold NPs (29)

Polymeric nanoparticles are widely investigated nanoparticles in clinical trials, and received much attention after the initial work of Langer and Folkman in 1976 (30). Because of their biodegradability, biocompatibility, high drug loading, stability and flexibility, polymeric nanoparticles are used for controlled release of drug. They usually consist of a general core-shell structure and are also subdivided into various categories according to their basic chemical and core shell composition and their morphology, including nanocapsules (NCs) and nanospheres (NSs). Nanocapsules are hollow spherically-shaped vesicular 
particles, where the drug is confined to a hollow core, usually composed of oil droplets, which is surrounded by a polymeric shell or membrane (31). Nanospheres are solid colloidal matrix systems, ideally uniform in their core-shell polymer partition, where a drug is dispersed or dissolved in the polymer matrix (32) (Fig. 1). Various synthetic and natural polymers currently being investigated for the design and potential applications of nanoparticles are polyethylene glycol (PEG), poly lactic acid (PLA) and poly D,L-lactide co-glycolide) (PLGA) and their copolymers PEG-PLA, PEG-PGA, PLGA and PEG-PLGA; these nanocarriers are the most widely investigated synthetic polymers for drug and gene delivery (3338). 


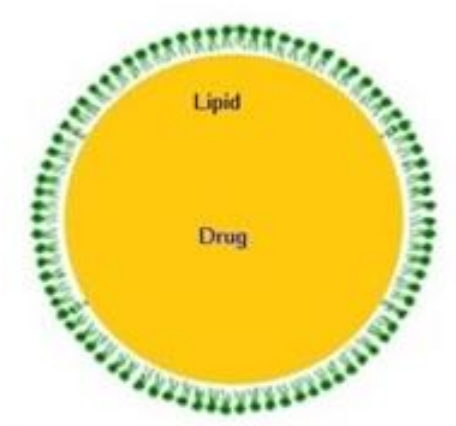

Lipid nanoparticles

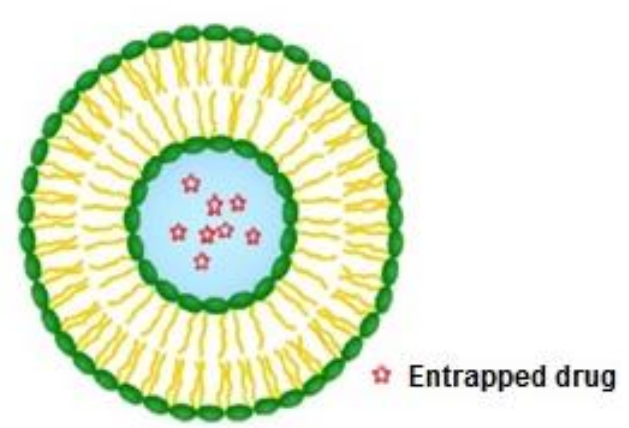

Liposomes

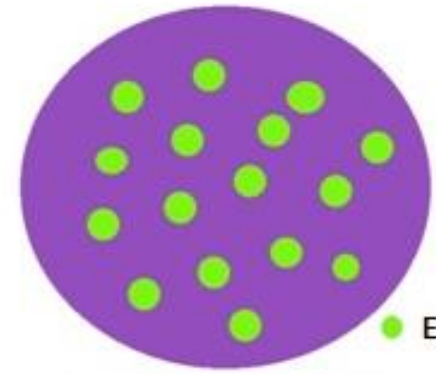

Nanospheres

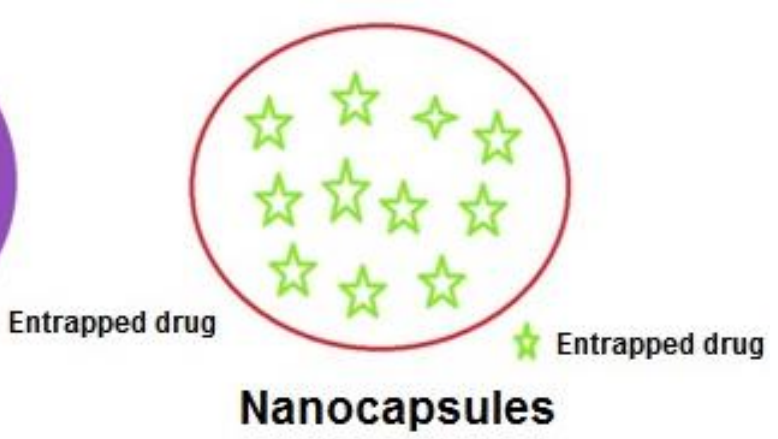

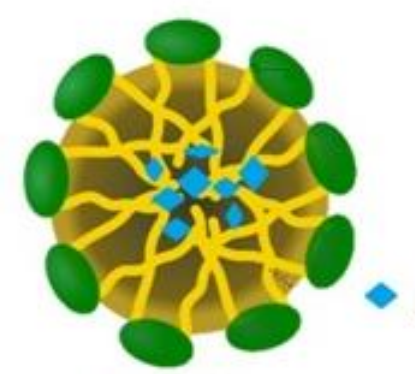

Micelles
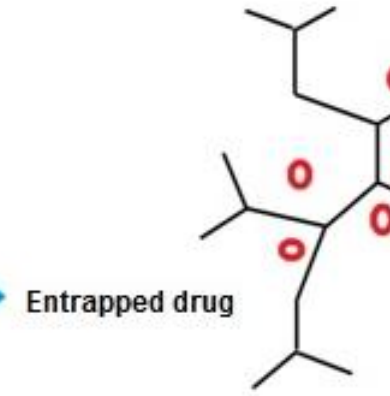

Dendrimers

Figure 1. Basic structure of nanoparticles used for cancer therapy entrapped with drug (Source : With permission from Katayoun et al., 2015 Active-targeted Nanotherapy as Smart Cancer Treatment ) (39). 
Table 1

Summary of characteristics and representative applications of various nano systems

\begin{tabular}{|l|l|l|l|l|}
\hline $\begin{array}{l}\text { Nano } \\
\text { particle }\end{array}$ & Size $(\mathrm{nm})$ & $\begin{array}{l}\text { Characteristic } \\
\text { properties }\end{array}$ & Applications & Ref \\
\hline $\begin{array}{l}\text { Carbon- } \\
\text { nanotubes }\end{array}$ & $0.5-3$ & $\begin{array}{l}\text { Cylindrical tube of } \\
\text { crystal carbon sheets, } \\
\text { Biocompatible }\end{array}$ & $\begin{array}{l}\text { Drug, gene and } \\
\text { peptide delivery }\end{array}$ & $(23)$ \\
\hline $\begin{array}{l}\text { Highly branched } \\
\text { synthetic polymeric } \\
\text { structures, } \\
\text { low polydispersity, } \\
\text { Biocompatible }\end{array}$ & $\begin{array}{l}\text { Controlled drug } \\
\text { delivery }\end{array}$ & $(28)$ \\
\hline Liposomes & $50-100$ & $\begin{array}{l}\text { Phospholipid bilayered } \\
\text { vesicles, Biocompatible } \\
\text { and good entrapment } \\
\text { efficiency }\end{array}$ & $\begin{array}{l}\text { Passive and active } \\
\text { drug delivery of } \\
\text { drugs, gene, } \\
\text { peptides and } \\
\text { others }\end{array}$ & $(25)$ \\
\hline $\begin{array}{l}\text { Polymeric } \\
\text { micelles }\end{array}$ & $10-100$ & $\begin{array}{l}\text { Hydrophobic core } \\
\text { wrapped by single layer } \\
\text { of hydrophilic polymers, } \\
\text { high drug entrapment, } \\
\text { payload, biostability }\end{array}$ & $\begin{array}{l}\text { Active and passive } \\
\text { drug delivery, cell } \\
\text { specific targeting }\end{array}$ & $(26)$ \\
\hline $\begin{array}{l}\text { Polymeric } \\
\text { NPs }\end{array}$ & $10-1000$ & $\begin{array}{l}\text { Biodegradable, } \\
\text { Biocompatible, } \\
\text { complete protection of } \\
\text { drug }\end{array}$ & $\begin{array}{l}\text { Site selective } \\
\text { delivery, excellent } \\
\text { carrier for } \\
\text { controlled and } \\
\text { sustained drug } \\
\text { delivery }\end{array}$ & (23) \\
\hline Gold & $<100$ & $\begin{array}{l}\text { Syperthermia, } \\
\text { surface area, } \\
\text { biocompatible }\end{array}$ & $\begin{array}{l}\text { diagnostivery, } \\
\text { radiotherapy } \\
\text { enhancement }\end{array}$ & $(40)$ \\
\hline
\end{tabular}


Despite the variety of nanomaterials designed for tumor targeting, only a limited number of formulations are clinically approved (Table 4). Treatment efficacy is often impeded by nonspecific drug distribution and lack of specificity to the target tissue site. Ideally, enhancing drug accumulation at the site of tumor will lower the systemic exposure and result in a more efficient and patient-friendly treatment. Several drug-targeting strategies can be engaged to reach target tissues. These include active and passive targeted drug delivery which are described in Chapter II. Targeted delivery of anticancer agents is a rapidly evolving and is a highly promising field of research. Indeed, targeted drug delivery potentially increases the local concentration of the fraction of the systemically administered dose reaching the tumor site, minimizing toxicity to the adjacent healthy cells. A particular focus has been the active targeting of nano drug delivery systems for the treatment of cancer because of the discovery of new molecular targets, a deep understanding of biology of cancer, and the failure of conventional treatment. Together, these lead to the enormous interest in developing tumor targeted nanomedicine for the development of novel drug delivery systems. 


\section{CHAPTER II}

\section{DRUG TARGETING MECHANISMS}

The key to success in cancer treatment is the therapeutic concentration at the tumor site. The concentration of therapeutic agent reaching the tumor tissue should be precise after crossing and penetrating all the biological barriers in the body. Once the drug is at the active site, it should selectively destroy the cancer cells, avoiding healthy tissues to reduce adverse effects and toxicity. To achieve these goals, nanoparticle drug delivery systems use the characteristics of the disease tissue to target their payloads. The drug-loaded nanoparticles reach the tumor site by two of the principal mechanisms: passive and active drug targeting. 


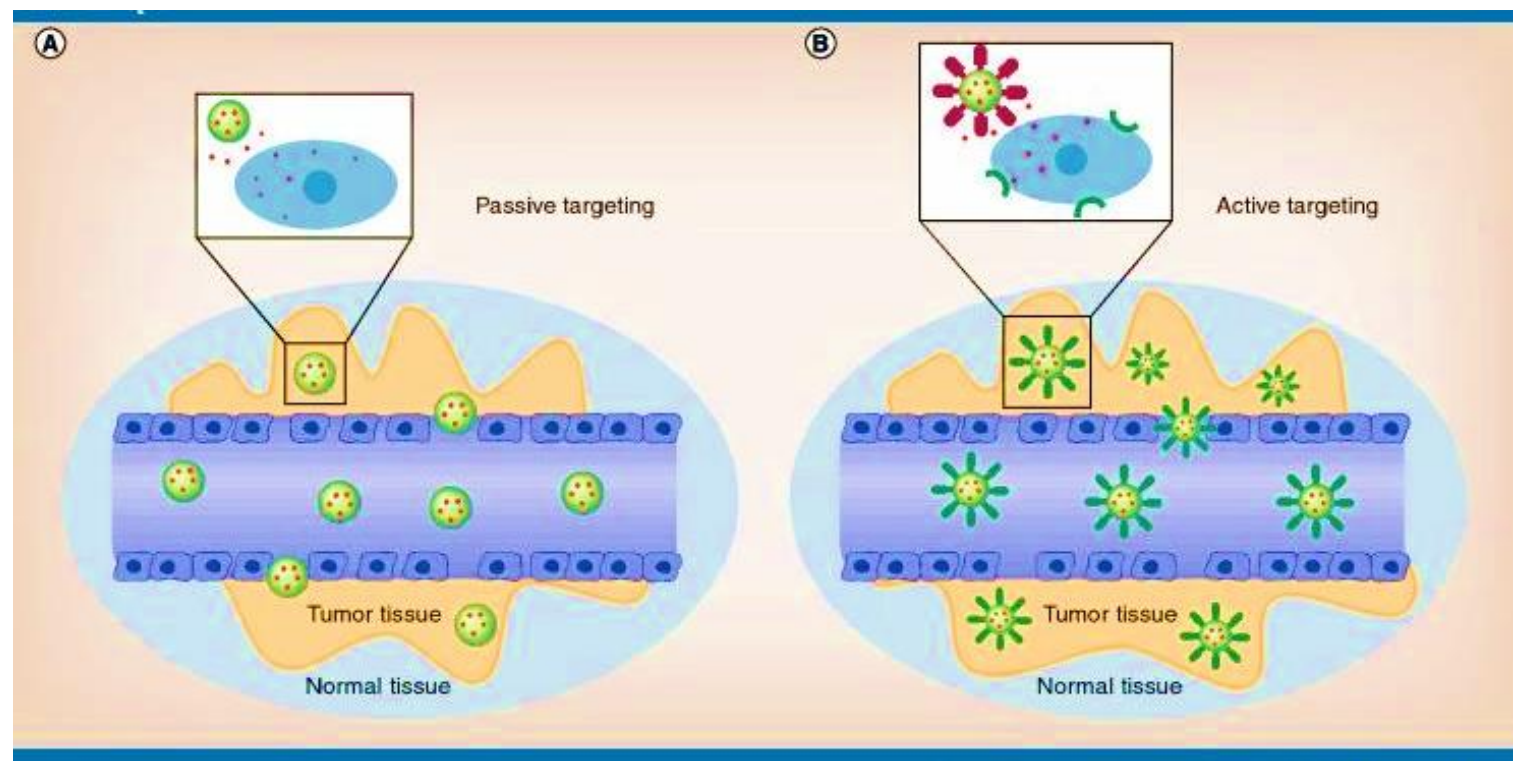

Figure 2. Passive and active targeting to enhance permeability and retention., Nanoparticles (NPs) can be passively extravasated through leaky vascularization, allowing their accumulation at the tumor region (A). In this case, drugs may be released in the extracellular matrix and then diffuse throughout the tissue or tumor. Active targeting (B) can enhance the therapeutic efficacy of drugs by increasing accumulation and cellular uptake of NPs through receptormediated endocytosis. (Source: With permission from Suwassa et al., A focus on nanoparticles as drug delivery system) (41). 
Passive drug Targeting

Nanoparticles drug delivery systems use pathophysiological characteristics of the tumor vasculature through the enhanced permeability and retention (EPR) effect. The EPR concept was originally described by Maeda et al., 1986 and this theory is based on the characteristics of tumor vasculature of leaky blood vessels and lack of lymphatic drainage (42). This allows the diffusion of longer circulating nanoparticles to the tumor site, avoiding health tissues, and thereby being selectively site-specific $(43,44)$. Most passive-targeting nanoparticles are surface-coated with PEG for biocompatibility, e.g., SP1049C, Genexol- PM, NK911 $(45,46)$ in early clinical trials for treating various types of cancer.

However, high heterogeneity of the EPR effect in tumors which varies from patient to patient and within same subject is a significant limitation to this strategy (47). The determination of precise impact of the EPR effect on nanoparticle accumulation in tumor tissues becomes difficult since a variety of parameters including size, shape, and zeta potential of nanoparticles are involved in this process. Only a small part of injected dose is accumulated in target cancer tissues which becomes a significant restriction in passive drug strategy (42). In view of these limitations of passive targeting a considerable amount of work is done and focused on developing active drug-targeting strategies. 
Active drug Targeting:

Active drug targeting is aimed at delivery of active drug selectively to the tumor site. Active drug-delivery strategies comprise use of a targeting ligand or moiety attached on the surface of nanocarrier, which recognizes and enables the nanoparticle to bind to receptors (tumor-specific epitope) overexpressed on tumor cells. These receptors serve as tumor markers which are either expressed at lower levels or essentially not expressed on normal cells. The interaction between ligand and receptor is affected by binding affinity and selectivity of the targeting unit and by the targeted receptor's capacity (48). Receptor levels depend not only on synthesis and stability, but also on recycling rate after receptor activation and internalization (49). Hence the binding affinity of the targeting ligand and number of ligand units conjugated and decorated on the surface are the important factors affecting targeting efficiency. To target the nanoparticles effectively to the desired site it is essential to have sufficient quantity of ligands/targeting moieties along with high affinity binding to cell surface receptors (50). Therefore, the most important feature of the targeting ligand is to induce receptor-mediated endocytosis causing the internalization of the drug carrier into the desired tumor tissue specific intracellular site $(51,52)$.

Currently there are many approaches available for active targeting to tumor cells. All the ligands that can be attached to the nanoparticles can serve as targeting moieties. There are wide variety of tumor-targeting moieties including small molecules, peptides, monoclonal antibodies, aptamers and 
nucleic acids which specifically recognize receptors overexpressed on tumor cell surface which will be discussed in Chapter III.

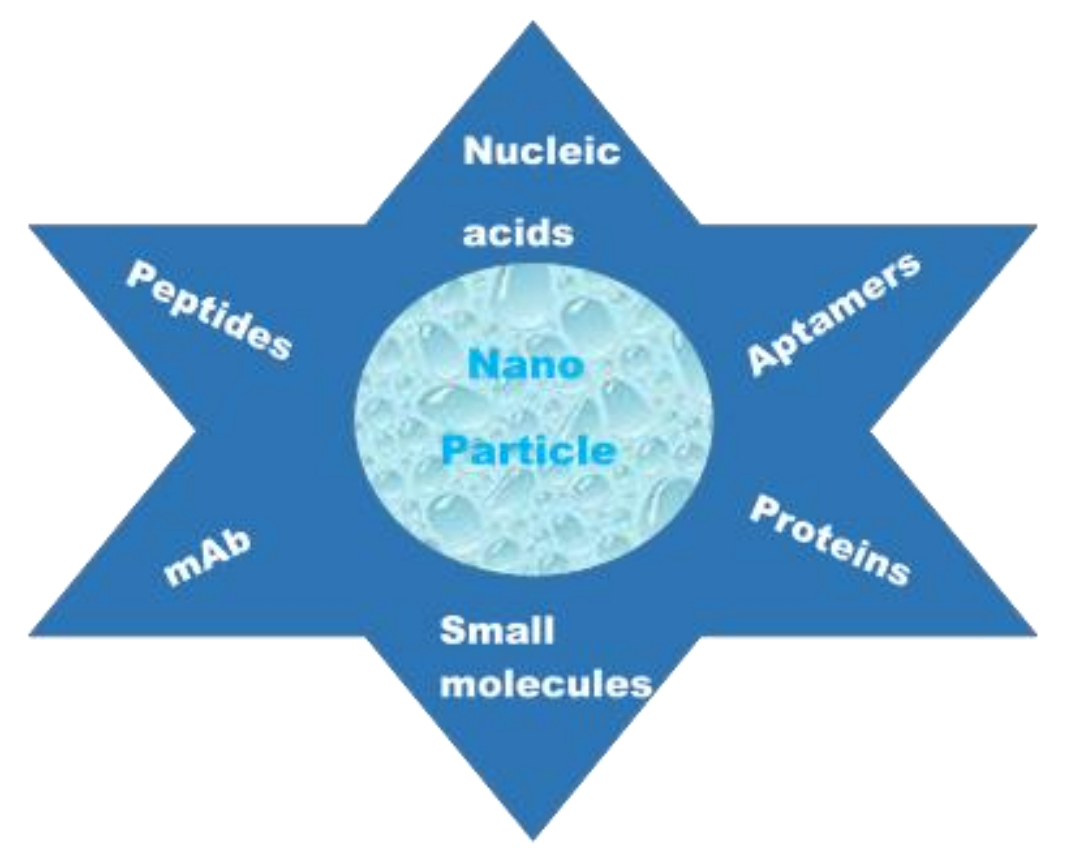

Figure 3. Types of ligands decorated on surface of nanoparticles for tumor targeting. 


\section{CHAPTER III \\ TYPES OF LIGANDS FOR ACTIVE TARGETING}

The identity and characteristics of the targeting ligands are extremely important for circulation time, cellular uptake, affinity, and extravasation. Targeting ligands can be broadly classified as proteins (mainly antibodies and their fragments), nucleic acids (aptamers), or other small molecules (peptides, vitamins, and carbohydrates).

Monoclonal Antibodies (mAb)

Targeting cancer with a mAb was described by Milstein in 1981 (53). mAbs bind to a receptor on the cell surface to induce several antibody-based anticancer mechanisms including antibody-dependent cellular cytotoxicity (ADCC) and complement-dependent cellular toxicity $(C D C)(54,55)$. The feasibility of antibody-based tissue-targeting has been clinically demonstrated with 17 different mAbs approved by the US Food and Drug Administration (FDA) (56). The mAb rituximab (Rituxan) was approved in 1997 for treatment of patients with non-Hodgkin's lymphoma - a type of cancer that originates in lymphocytes (57). A year later, Trastuzumab (Herceptin), an anti-HER2 mAb that binds to ErbB2 receptors, was approved for the treatment of HER2+ breast cancer (58). The first angiogenesis inhibitor for treating colorectal cancer, Bevacizumab (Avastin), an anti-VEGF mAb that inhibits the growth of new blood 
vessels, was approved in 2004 (59). Today, over 200 delivery systems based on antibodies or their fragments are in preclinical and clinical trials (60). Recent developments in the field of antibody engineering have resulted in the production of antibodies that contain animal and human origins such as chimeric mAbs, humanized mAbs (those with a greater human contribution), and antibody fragments. However, there are several limitations to this approach including immunogenicity, large size, and cost of mAb synthesis, rapid clearance, and environmental factors. The use of antibody fragments like Fab and single chain variable fragments reduce the immunogenicity by keeping high antigen binding specificity (52).

\section{Aptamers}

Aptamers are another emerging class of targeting ligands which are short single-stranded RNA or DNA sequences of oligonucleotides that can be designed as targeting ligand capable of binding to target receptors on the surface of cancer cells with high selectivity and affinity (61). They form unique three-dimensional structures with high ligand binding specificity needed for target affinity. They are small size $(\sim 15 \mathrm{KDa})$, less immunogenic when compared to antibodies, and can be chemically synthesized. Several aptamers have been developed to bind specifically to receptors on cancer cells, and can be considered suitable for nanoparticle-aptamer conjugate therapy (62). Docetaxel (Dtxl)-encapsulated nanoparticles with aptamer (targets the antigen on the surface of prostate cancer cells) functionalized surface were delivered with high selectivity and efficacy in vivo (63). Similarly, doxorubicin encapsulated 
DOTAP nanoparticles functionalized with DNA-based aptamer demonstrated a significant reduction in tumor growth in a tumor xenograft model (64). RNAbased aptamers have also been developed which can selectively bind to the $T$ cell factor 1 and beta catenin in colon cancer cells (65-67). Locked nucleic acidmodified aptamers (LNA) used in iron oxide saturated lactoferrin nanocarriers demonstrated improved survival rate in colon cancer xenograft (68). RNA-A10 aptamer PMSA (prostate specific membrane antigen) has also been reported for better therapeutic efficacy (69-71).

Protein/peptides

A variety of proteins/peptides have been investigated for tumor targeting. Several endogenous proteins which bind specifically to cell surface receptors have been used for targeting purposes (72). For example, transferrin, a protein involved in transport of iron, binds specifically to transferrin receptors which are overexpressed in variety of malignancies. Choi et al. showed that transferrin decorated PEGylated gold nanoparticles accumulated specifically in cancer cells avoiding nonspecific transport of nanoparticles to the healthy cells $(73,74)$. Muthu et al. demonstrated the enhanced efficacy of transferrin-functionalized vitamin E-based micellar nanosystems in MDA-MB 231 breast cancer cells (18). Jain et al. showed that transferrin-based nanosystems improved the antitumor activity against breast cancer cells (21). Krishna et al. developed a unique transferrin receptor targeting using apotransferrin protein as drug carrier for nanoparticles (75). 
In addition to proteins, various peptides have also been used as targeting ligands, which are specific to the receptors overexpress on tumor cells. In order to find the best suitable peptide for targeting ligand, several peptide phage display libraries are available for identification of specific targeting ligands (76). A tumor homing penta-peptide CREKA that recognizes fibrin-associated plasma protein has been used as a targeting ligand on iron oxide nanoparticles and liposomes (77). Also penta-peptide LFC-131, an antagonist for CXCR4, a chemokine responsible for majority of inflammatory related cancers, has been used as a targeting ligand on polymeric nanoparticles for targeting CXCR4 overexpressed in cancer cells (78). Peptides have also been reported for the receptor proteins viz. interleukin 11 receptor $\alpha(\mathrm{IL}-11 \mathrm{Ra})$ and $78 \mathrm{KDa}$ glucoseregulated protein (GRP78) in prostate and breast tumors (79-81). Among the different peptides, RGD peptide is a commonly used targeting ligand, which selectively binds to $\alpha \vee \beta 3, \alpha v \beta 5$ integrin (angiogenesis markers) overexpressed in endothelial and smooth muscle cells of tumor blood vessels. In an earlier investigation by Danhier et al. (2009) RGD-decorated paclitaxel-loaded nanoparticles demonstrated significantly enhanced tumor growth inhibition and prolonged animal survival (82). RGD-conjugated PLGA NPs have also shown enhanced antitumor efficacy in vivo (83). 
Small molecules

Small molecules with molecular weight less than $500 \mathrm{Da}$ are a promising class of targeting ligands because of their small size, low cost of synthesis, and high stability. Pomper et al. identified small hydrophilic molecules from ureabased PMSA inhibitors which specifically target PMSA receptor overexpressed on the surface of prostate cancer cells (84). Chandran et al. developed docetaxel-encapsulated PLA/PCL-based targeted nanoparticles using PMSA as a targeting moiety (85). This moiety proved to be an efficient targeting ligand for the uptake of nanoparticles by PMSA-overexpressing cells. This small molecule is also used as a targeting ligand for the development of a novel polymeric nanoparticle BIND-014, composed of biodegradable hydrophobic PLA polymeric core and hydrophilic PEG. This is the first targeted- and controlled-release polymeric nanoparticle to reach clinical phase I trials for cancer chemotherapy (86).

Among the different targeting strategies, vitamins are another class of molecules widely investigated for tumor targeting. The vitamins employed for targeting include folate, vitamin $\mathrm{B} 12$, thiamine, and biotin. The principal advantages associated with vitamins, particularly folic acid, include stability (both on the shelf and in the body), relative cost (low), lack of toxicity and immunogenicity, and wide flexibility for diverse chemical reactions (87). Folic acid has been widely investigated as a ligand in targeted drug delivery (88-90). Folic acid has high affinity for folate receptors which are over expressed in many types of solid tumors such as ovarian, lung, uterine, breast, head and neck cancers 
(91). Besides the different tumors, folate has also been used as targeting ligand for delivery of many drug conjugates and delivery systems including liposomes, polymeric NPS through folate receptor mediated endocytosis (92). Folic acidfunctionalized PLGA nanoparticles and deoxycholic acid-o-carboxymethylated chitosan-folic acid micelles have shown enhanced efficacy of doxorubicin and paclitaxel, respectively $(93,94)$. 
Table 2

Examples of targeting ligands used in anticancer nanoformulations

\begin{tabular}{|c|c|c|c|c|}
\hline $\begin{array}{l}\text { Targeting } \\
\text { ligand }\end{array}$ & Receptor & Nanoformulation & Indication & Ref \\
\hline Folate & $\begin{array}{l}\text { Folate } \\
\text { receptor }\end{array}$ & $\begin{array}{l}\text { PLGA polymeric NPs- } \\
\text { Doxorubicin }\end{array}$ & Breast cancer & (93) \\
\hline Folate & $\begin{array}{l}\text { Folate } \\
\text { receptor }\end{array}$ & $\begin{array}{l}\text { Deoxy cholic acid-o- } \\
\text { carboxymethylated } \\
\text { chitosan-folic acid } \\
\text { micelles- Paclitaxel }\end{array}$ & Breast cancer & (94) \\
\hline Folate & \begin{tabular}{|l|} 
Folate \\
receptor
\end{tabular} & $\begin{array}{l}\text { Chitoson polyplex } \\
\text { liposomes- Nucleic acid }\end{array}$ & Melanoma & (95) \\
\hline RGD & $\begin{array}{l}\alpha v \beta 3, \alpha v \beta 5 \\
\text { integrin } \\
\text { receptors }\end{array}$ & $\begin{array}{l}\text { RGD modified } \\
\text { liposomes-paclitaxel }\end{array}$ & $\begin{array}{l}\text { Hepatocellular } \\
\text { carcinoma }\end{array}$ & (96) \\
\hline Transferrin & $\begin{array}{l}\text { Transferrin } \\
\text { receptor }\end{array}$ & $\begin{array}{l}\text { Lipid coated PLGA } \\
\text { Nps- Aromatase } \\
\text { inhibitor }\end{array}$ & Breast Cancer & (97) \\
\hline Transferrin & $\begin{array}{l}\text { Transferrin } \\
\text { receptor }\end{array}$ & $\begin{array}{l}\text { Vit E TPGS micelles- } \\
\text { Doxirubicin }\end{array}$ & Breast Cancer & (18) \\
\hline Transferrin & $\begin{array}{l}\text { Transferrin } \\
\text { receptor }\end{array}$ & $\begin{array}{l}\text { PLGA polymeric NPs- } \\
\text { Methotrexate }\end{array}$ & Brian cancer & (21) \\
\hline EGFR & \begin{tabular}{|l|} 
EGFR \\
receptor \\
\end{tabular} & $\begin{array}{l}\text { DSPE-PEG lipid } \\
\text { polymeric complex }\end{array}$ & $\begin{array}{l}\text { Hepatocellular } \\
\text { Carcinoma }\end{array}$ & (98) \\
\hline EGFR & $\begin{array}{l}\text { EGFR } \\
\text { receptor }\end{array}$ & $\begin{array}{l}\text { Poly(lactic acid-co-l- } \\
\text { lysine) nanoparticles }\end{array}$ & $\begin{array}{l}\text { Hepatocellular } \\
\text { Carcinoma }\end{array}$ & (99) \\
\hline $\begin{array}{l}\text { Fibrin } \\
\text { associated } \\
\text { plasma } \\
\text { proteins }\end{array}$ & $\begin{array}{l}\text { Clotted } \\
\text { Plasma } \\
\text { proteins of } \\
\text { tumor vessels }\end{array}$ & $\begin{array}{l}\text { CREKA conjugated } \\
\text { liposomes-Doxirubicin }\end{array}$ & Breast Cancer & (77) \\
\hline Aptamers & Tumor DNA & $\begin{array}{l}\text { DOTAP Liposomes- } \\
\text { Doxirubicin }\end{array}$ & Breast Cancer & $(100)$ \\
\hline Aptamers & CD133 & $\begin{array}{l}\text { PEGYLATED PLGA } \\
\text { NPS }\end{array}$ & $\begin{array}{l}\text { Hepatocellular } \\
\text { Carcinoma }\end{array}$ & (101) \\
\hline Aptamers & $\begin{array}{l}\text { EGFR } \\
\text { receptor }\end{array}$ & $\begin{array}{l}\text { Triple function RNA } \\
\text { NPs }\end{array}$ & $\begin{array}{l}\text { Triple- } \\
\text { negative } \\
\text { Breast Cancer }\end{array}$ & (78) \\
\hline
\end{tabular}


Bioconjugation for surface-functionalization of nanocarriers

In spite of the availability of a wide variety of targeting ligands, surface functionalization remains a challenge. The major requirement for surface functionalization is the presence of a targeting ligand on the NPs surface until the active load is delivered to the target site. To make the functionalization stable over the NP surface, a conjugation strategy that covalently links the ligands over the surface of the NPs by using simple chemistry was established $(102,103)$. The selection of the appropriate conjugation strategy is an important step, as the chemicals used for the conjugation may affect the targeting ligand during the process of conjugation (104). The most commonly used covalent conjugation approaches are through amide linkages, which link carboxyl group to amine using carbodiimide chemistry. It occurs by activation of carboxylic group present on the NP surface by EDC (1-ethyl-3-(3-dimethyl amino propyl) carbodiimide and NHS (N-hydroxysuccinimide) forming reactive intermediate which couples with amine groups present in targeting ligand.

The chemical conjugation approach has been reported by Kocbek et al. to functionalize the PLGA NPs by using Mb as targeting ligand and by Acharya et al. who developed the nanoparticle bioconjugate by using epidermal growth factor (EGF) as A targeting ligand $(105,106)$. In addition to the use of carboxylic and amino groups, thiol functional groups have also been reported to form disulfide bonds for surface functionalization (107). Thiol group can react with other thiol group to form disulfide bond and also react with maleimide group to form thioether groups. Shaik et al. used the similar concept of forming disulfide 
bond to conjugate anti-My9 antibody to stealth liposomes (107). Similarly, several other reports also demonstrated disulfide bond formation as a conjugation strategy between maleimide processing NPs and thiol-bearing ligands and vice versa $(83,104,108)$. The highly specific, non-covalent reaction between avidin and biotin has been used to functionalize avidin containing liposomes with biotinylated antibodies (109). Other reaction complexes with streptavidin and neutravidin are also in public domain for conjugation (110). Although these noncovalent binding techniques are available, the immunogenic reactions due to the source of avidin make this approach the second choice after covalent conjugation (111).

'Click' chemistry is another interesting technique to conjugate targeting moieties to NPs (112). The use of click reactions became prevalent because of their high efficiency, specificity, ease of availability of reagents, low nonspecific binding, and physiological stability as compared to traditional crosslinking carbodiimide chemistry. Click chemistry is a single step reaction carried out under mild conditions in aqueous solutions producing high yield of product. It involves reaction between azide and alkyne under various conditions and the major classes of reactions involved are cooper-catalyzed azide-alkyne cycloaddition (CuAAC), Strain- promoted azide-alkyne click chemistry (SPAAC) and Tetrazine-trans-cyclooctene (TCO) ligation $(113,114)$. Koo et al. have reported the biorthogonal copper free click chemistry for tumor targeted delivery of nanoparticles (115). 
Exosome-mediated drug delivery as an emerging nanomedicine approach

Exosomes are lipid bilayer biological nanoparticles secreted by all the cells in the body, present in almost all the body fluids, and play an important role in cell-to-cell communication (116-119). Exosomes are emerging as potential drug delivery nano vehicle (Figure 4). Exosomes have the advantages of being less immunogenic and showing better biological tolerability and cellular internalization compared with synthetic NPs $(118,120-122)$. There is a growing interest in exploiting these biological NPs for delivering chemotherapeutics and genetic material to the tumor site. With this growing interest, surface functionalization of exosomes for selective delivery of chemotherapeutics and siRNAs to cancer cells have been reported (123-125). Exosomes isolated from different sources and the different small molecules delivered are summarized in Table 3. 


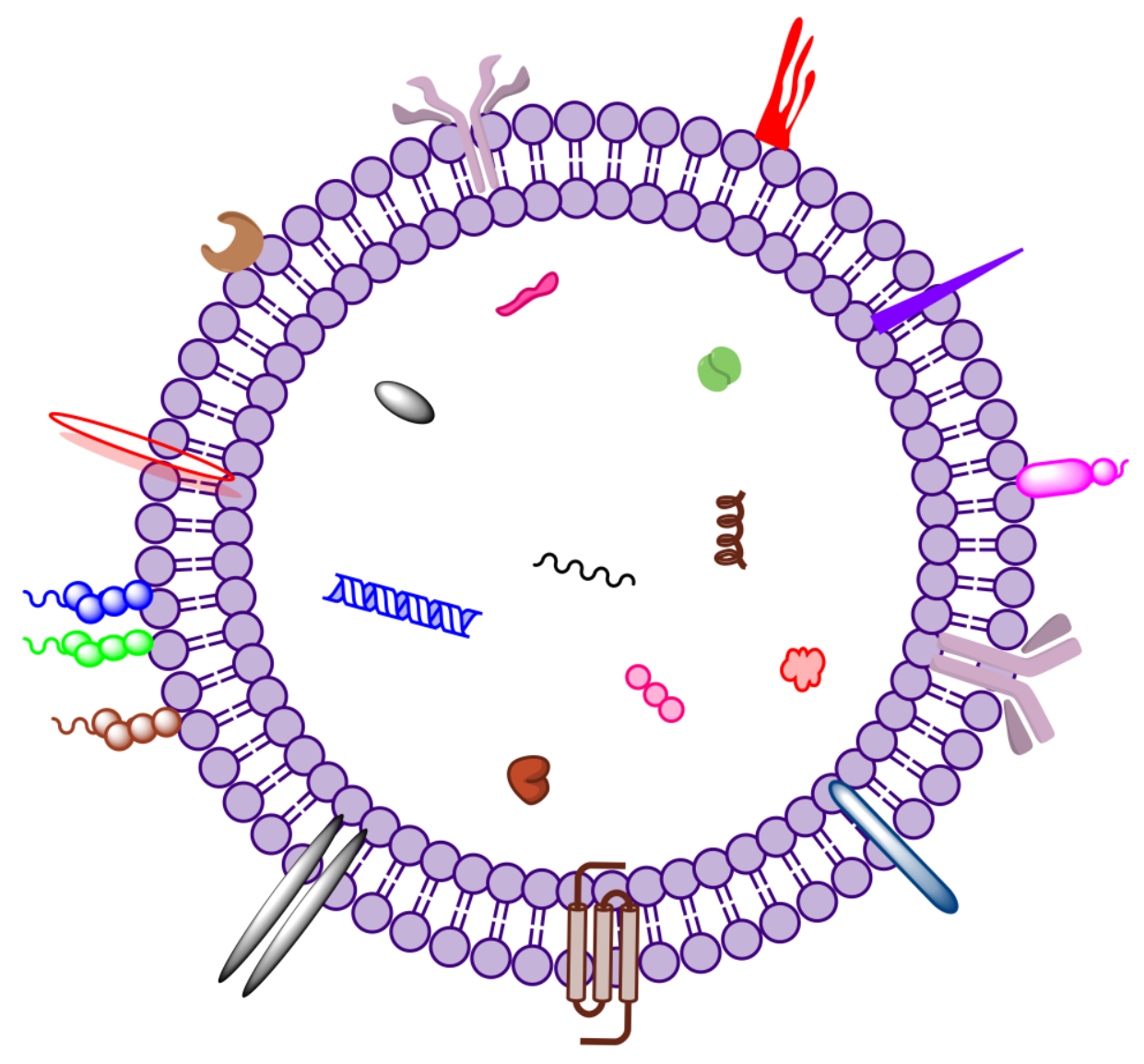

Figure 4. Diagram depicting the structure of exosome carrying lipid, DNA, RNA and protein (Source: With permission from Munagala et al., 2016 Bovine milk derived exosomes for drug delivery) (126). 
Table 3

Therapeutic applications of Exosomes as nanocarriers

\begin{tabular}{|l|l|l|l|l|}
\hline Source & Cargo & $\begin{array}{l}\text { Target cancer } \\
\text { type }\end{array}$ & Outcome & Ref \\
\hline Bovine milk & Witheferin- A & $\begin{array}{l}\text { Breast and } \\
\text { Lung cancer }\end{array}$ & $\begin{array}{l}\text { Tumor growth } \\
\text { inhibition }\end{array}$ & $(126)$ \\
\hline Bovine milk & Celastrol & Lung cancer & $\begin{array}{l}\text { Tumor growth } \\
\text { inhibition }\end{array}$ & $(127)$ \\
\hline Bovine milk & Paclitaxel & Lung cancer & $\begin{array}{l}\text { Tumor growth } \\
\text { inhibition }\end{array}$ & $(128)$ \\
\hline $\begin{array}{l}\text { Mouse Dendritic } \\
\text { cells }\end{array}$ & Doxorubicin & Breast cancer & $\begin{array}{l}\text { Tumor growth } \\
\text { inhibition }\end{array}$ & $(129)$ \\
\hline $\begin{array}{l}\text { Breast cancer } \\
\text { cells }\end{array}$ & Doxorubicin & $\begin{array}{l}\text { Breast and } \\
\text { Ovarian cancer }\end{array}$ & $\begin{array}{l}\text { Tumor growth } \\
\text { inhibition }\end{array}$ & $(130)$ \\
\hline $\begin{array}{l}\text { Prostate cancer } \\
\text { cells }\end{array}$ & Paclitaxel & $\begin{array}{l}\text { Prostate } \\
\text { cancer }\end{array}$ & $\begin{array}{l}\text { Increased } \\
\text { cytotoxicity }\end{array}$ & $(131)$ \\
\hline Machrophage & Paclitaxel & Lung cancer & $\begin{array}{l}\text { Tumor growth } \\
\text { inhibition }\end{array}$ & $(132)$ \\
\hline $\begin{array}{l}\text { Mesenchymal } \\
\text { stem cells }\end{array}$ & mir-122 & $\begin{array}{l}\text { Hepatocellular } \\
\text { carcinoma }\end{array}$ & $\begin{array}{l}\text { Tumor growth } \\
\text { inhibition }\end{array}$ & $(133)$ \\
\hline $\begin{array}{l}\text { Mesenchymal } \\
\text { stem cells }\end{array}$ & mir-143 & Osteosarcoma & $\begin{array}{l}\text { Inhibition of } \\
\text { migration }\end{array}$ & $(134)$ \\
\hline Monocytic cell & c-Myc siRNA & Lymphoma & $\begin{array}{l}\text { Induction of } \\
\text { apoptosis }\end{array}$ & $(135)$ \\
\hline BEK 293 cell & Bladder cancer & $\begin{array}{l}\text { Induction of } \\
\text { apoptosis }\end{array}$ & $(136)$ \\
\hline
\end{tabular}


The field of exosomes as NPs is rather young and its use as a nanocarrier to deliver cytotoxic drugs and phytochemical compounds has recently been explored with encouraging results $(126,127,129,130,137-139)$. For example, Tian et al., 2014 and Srivastava et al., 2016 reported enhanced efficacy of doxorubicin exosomal formulations $(129,138)$. Moreover, some studies have shown enhanced therapeutic efficacy of cytotoxic drugs and natural compounds while encapsulating these compounds in exosomes $(127,130,131,137,139)$. Saari et al. showed that cytotoxic effect of paclitaxel to prostate cancer cells increased when encapsulated in exosomes (131). Milk derived exosomes have been reported to enhance therapeutic response of withaferin A (126) and celestrol (127), as well as to enhance the stability and therapeutic response of anthocyanidins (139) in various cancers. Zhuang et al. showed that the exosomal formulations of curcumin inhibited LPS-induced inflammation in a mouse model compared with free curcumin and reported their positive effects against brain tumor when given through intranasal route (137).

Due to their high complexity and variable composition, the cell specificity of these exosomes is not predictable, leading to non-specific targeting. Such offtarget effects can be minimized through active targeting by functionalizing extracellular vesicles with targeting ligands. Exosomes are functionalized in several ways by decorating with specific ligands to improve the targeting ability $(129,140,141)$. Folic acid-functionalized milk-derived exosomes were shown to enhance the therapeutic efficacy of withaferin A against lung cancer in vitro and in vivo (126). The peptide $\mathrm{i}-\mathrm{RGD}$, which is specific to the $\alpha v \beta 3$ integrin receptor 
that overexpressed in cancer cells, has been reported to fuse to the exosomal membrane proteins and lipids, i.e., Lamp2b and glycosylphosphatidylinositol (142). Alvarez et al. showed siRNA delivery to mouse brain by functionalizing exosomes with RVG peptide by fusing with Lamp2b exosomal membrane protein. These RVG exosomes could bind to specific receptor overexpressed in brain tumors. Tian et al. used the same mechanism to deliver doxorubicin to breast cancer cells (129). Chemical conjugation techniques, similar to those used for NPs, have also been used for the functionalization of exosomes (143). Kooijmans et al. reported a post insertion technique for exosome functionalization. In this technique, EGFR nanobody-conjugated PEG phospholipid micelles were mixed with extracellular vesicles derived from Neuro 2A cells (143). Click chemistry has also been used for making functionalized exosomes (144).

Clinical status

To date only a handful of nanoformulations are FDA approved and available for clinical use. Liposomal formulations like Doxil ${ }^{\mathrm{R}}$, Myocet, DaunoXome, Depocyt, polymeric nanoparticles such as $A_{b r a x a n e^{R}}$, and polymeric micelles like Glenexol-PM are FDA approved. The majority of the FDAapproved nanomedicines were developed based on passive targeting which utilizes the EPR effect, due to the leaky vasculature of the tumor. There are certain functionalized nanoformulations which have been specifically designed to undergo ligand-mediated targeting selective to tumor site. The clinical status of novel nanoformulations has been summarized in Table 4 . 
MCC-465 is a novel PEGylated liposomal formulation encapsulating doxorubicin tagged with human monoclonal antibody fragment $F\left(a b^{\prime}\right)$ in Phase I clinical trial against metastatic stomach cancer (145). Recently, a PEGylated liposomal formulation of doxorubicin functionalized with $F(a b$ ') fragment of antibody cetuximab (C225) was approved for clinical use (146). Liposomal formulation of oxaliplatin (SGT53) functionalized with single chain antibody fragment (TfRscFv) as targeting ligand is in a Phase I of clinical trial (147). Cyclodextrin-based nanoparticles (CALAA-01) is the first nanoformulation in clinical trial for the siRNA delivery to tumor site (148). Heat-activated PEGylated liposomes containing doxorubicin (Thermodox) is in Phase III clinical trial for treating liver cancer (149). Similar to liposomal formulations, some polymeric nanoparticles are at different stages of clinical trials. PEG-poly(aspartic acid) polymeric nanoparticles like NK 105 and NK 911, and PEG-cyclodextrin nanoparticles like CRLX101 are in phase I and phase II clinical trials (150). Targeted-polymeric nanomedicines like BIND-014, PEGylated PL(G)A docetaxel formulation has completed the phase I and is now in Phase II clinical trials (86). 
Table 4

Summary of nanoformulations in market and clinical development

\begin{tabular}{|c|c|c|c|c|c|}
\hline $\begin{array}{l}\text { Nano } \\
\text { Carrier } \\
\text { type }\end{array}$ & $\begin{array}{l}\text { Product } \\
\text { Name }\end{array}$ & Formulation & Drug & Indication & $\begin{array}{l}\text { Clinical } \\
\text { Status }\end{array}$ \\
\hline \multirow{10}{*}{$\begin{array}{c}\text { Liposo } \\
\text { mes }\end{array}$} & $\begin{array}{l}\text { Doxil® } \\
\text { (Caelyx® in } \\
\text { EU) }\end{array}$ & $\begin{array}{l}\text { PEGylated } \\
\text { liposome }\end{array}$ & Doxorubicin & $\begin{array}{l}\text { Breast } \\
\text { cancer, } \\
\text { ovarian } \\
\text { cancer, } \\
\text { multiple } \\
\text { myeloma, } \\
\text { Kaposi's } \\
\text { sarcoma }\end{array}$ & Approved \\
\hline & Myocet® & $\begin{array}{l}\text { Non- } \\
\text { PEGylated } \\
\text { liposome }\end{array}$ & Doxorubicin & $\begin{array}{l}\text { Breast } \\
\text { cancer }\end{array}$ & Approved \\
\hline & $\begin{array}{l}\text { DaunoXome } \\
\text { () }\end{array}$ & $\begin{array}{l}\text { Non- } \\
\text { PEGylated } \\
\text { liposome }\end{array}$ & $\begin{array}{l}\text { Daunorubici } \\
\mathrm{n}\end{array}$ & $\begin{array}{l}\text { Kaposi's } \\
\text { sarcoma }\end{array}$ & Approved \\
\hline & DepoCyt® & $\begin{array}{l}\text { Non- } \\
\text { PEGylated } \\
\text { liposome }\end{array}$ & Cytarabine & $\begin{array}{l}\text { Lymphomat } \\
\text { us } \\
\text { meningitis, } \\
\text { leukaemia, } \\
\text { glioblastom } \\
\text { a }\end{array}$ & Approved \\
\hline & Lipoplatin & $\begin{array}{l}\text { PEGylated } \\
\text { liposome }\end{array}$ & Cisplatin & $\begin{array}{l}\text { Various } \\
\text { malignancie } \\
\mathrm{s}\end{array}$ & Phase III \\
\hline & S-CKD602 & $\begin{array}{l}\text { PEGylated } \\
\text { liposome }\end{array}$ & CKD-602 & $\begin{array}{l}\text { Various } \\
\text { malignancie } \\
\mathrm{s}\end{array}$ & Phase I/II \\
\hline & NL CPT-11 & $\begin{array}{l}\text { PEGylated } \\
\text { liposome }\end{array}$ & $\begin{array}{l}\text { Irinotecan } \\
\text { (CPT-11) }\end{array}$ & Glioma & Phase I \\
\hline & CPX-1 & Liposome & Irinotecan & $\begin{array}{l}\text { Colorectal } \\
\text { cancer }\end{array}$ & Phase II \\
\hline & LE-SN38 & Liposome & SN-38 & $\begin{array}{l}\text { Colorectal } \\
\text { cancer }\end{array}$ & Phase II \\
\hline & MBP-426 & $\begin{array}{l}\text { Tf-NGPE- } \\
\text { liposome }\end{array}$ & Oxaliplatin & $\begin{array}{l}\text { Various } \\
\text { malignancie } \\
\text { s }\end{array}$ & Phase II \\
\hline
\end{tabular}




\begin{tabular}{|c|c|c|c|c|c|}
\hline & MCC-465 & $\begin{array}{l}\text { Human } \\
\text { antibody } \\
\text { fragment } \\
\text { (GAH)- } \\
\text { PEG- } \\
\text { liposome }\end{array}$ & Doxorubicin & $\begin{array}{l}\text { Gastric } \\
\text { cancer }\end{array}$ & Phase I \\
\hline & $\begin{array}{l}\text { Thermodox } \\
\text { TM }\end{array}$ & $\begin{array}{l}\text { Heat- } \\
\text { activated } \\
\text { PEGylated } \\
\text { liposome }\end{array}$ & Doxorubicin & $\begin{array}{l}\text { Liver } \\
\text { cancer, } \\
\text { breast } \\
\text { cancer }\end{array}$ & Phase III \\
\hline & CPX-351 & Liposome & $\begin{array}{l}\text { Cytarabine+ } \\
\text { daunorubici } \\
\mathrm{n}\end{array}$ & $\begin{array}{l}\text { Acute } \\
\text { myeloid } \\
\text { leukaemia }\end{array}$ & Phase II \\
\hline & SGT-53 & $\begin{array}{l}\text { Transferrin- } \\
\text { targeted } \\
\text { DNA } \\
\text { plasmid } \\
\text { liposome }\end{array}$ & P53 gene & $\begin{array}{l}\text { Various } \\
\text { solid } \\
\text { malignancie } \\
\mathrm{s}\end{array}$ & Phase I \\
\hline \multirow{5}{*}{$\begin{array}{l}\text { Polyme } \\
\text { ric } \\
\text { nanopa } \\
\text { rticles }\end{array}$} & $\begin{array}{l}\text { Abraxane® } \\
(\mathrm{ABI}-007)\end{array}$ & $\begin{array}{l}\text { Albumin- } \\
\text { bound } \\
\text { nanoparticle } \\
\text { (nab) } \\
\end{array}$ & Paclitaxel & $\begin{array}{l}\text { Breast } \\
\text { cancer }\end{array}$ & Approved \\
\hline & BIND-014 & $\begin{array}{l}\text { PEG-PLGA } \\
\text { nanoparticle }\end{array}$ & Docetaxel & $\begin{array}{l}\text { Various } \\
\text { solid } \\
\text { malignancie } \\
\mathrm{s}\end{array}$ & Phase I \\
\hline & $\begin{array}{l}\text { Docetaxel- } \\
\text { PNP }\end{array}$ & $\begin{array}{l}\text { Polymeric } \\
\text { nanoparticle }\end{array}$ & Docetaxel & $\begin{array}{l}\text { Various } \\
\text { solid } \\
\text { malignancie } \\
\mathrm{s}\end{array}$ & Phase I \\
\hline & CRLX101 & $\begin{array}{l}\text { Cyclodextri } \\
\text { n-PEG } \\
\text { nanoparticle }\end{array}$ & $\begin{array}{l}\text { Camptothec } \\
\text { in }\end{array}$ & $\begin{array}{l}\text { Various } \\
\text { malignancies }\end{array}$ & Phase II \\
\hline & CALAA-01 & $\begin{array}{l}\text { Cyclodextri } \\
\text { n-PEG- } \\
\text { transferrin- } \\
\text { nanoparticle }\end{array}$ & $\begin{array}{l}\text { Anti-RRM2 } \\
\text { siRNA }\end{array}$ & $\begin{array}{l}\text { Various solid } \\
\text { malignancies }\end{array}$ & Phase I \\
\hline \multirow{3}{*}{$\begin{array}{l}\text { Polyme } \\
\text { ric } \\
\text { micelles }\end{array}$} & $\begin{array}{l}\text { Genexol- } \\
\text { PM® }\end{array}$ & $\begin{array}{l}\text { PEG-PLA } \\
\text { micelle }\end{array}$ & Paclitaxel & $\begin{array}{l}\text { Breast } \\
\text { cancer, lung } \\
\text { cancer, } \\
\text { ovarian } \\
\text { cancer }\end{array}$ & Approved \\
\hline & NK911 & $\begin{array}{l}\text { PEG-PAA } \\
\text { micelle }\end{array}$ & Doxorubicin & $\begin{array}{l}\text { Various solid } \\
\text { malignancies }\end{array}$ & Phase III \\
\hline & NK105 & $\begin{array}{l}\text { PEG-PAA } \\
\text { micelle }\end{array}$ & Paclitaxel & $\begin{array}{l}\text { Gastric } \\
\text { cancer }\end{array}$ & Phase II \\
\hline
\end{tabular}




\begin{tabular}{|c|c|c|c|c|c|}
\hline & $\begin{array}{l}\text { NC-6004 } \\
\text { (Nanoplain TM } \\
\text { ) }\end{array}$ & $\begin{array}{l}\text { PEG- } \\
\text { polyglutami } \\
\text { c acid } \\
\text { micelle }\end{array}$ & Cisplatin & $\begin{array}{l}\text { Pancreatic } \\
\text { cancer }\end{array}$ & Phase II \\
\hline & NK012 & $\begin{array}{l}\text { PEG-PGA } \\
\text { micelle }\end{array}$ & SN-38 & $\begin{array}{l}\text { Various solid } \\
\text { malignancies }\end{array}$ & Phase II \\
\hline & SP1049C & \begin{tabular}{|l|}
$\mathrm{P}-$ \\
glycoprotein \\
micelle
\end{tabular} & Doxorubicin & $\begin{array}{l}\text { Various } \\
\text { malignancies }\end{array}$ & Phase II \\
\hline & Paclical ${ }^{\circledR}$ & $\begin{array}{l}\text { Polymeric } \\
\text { micelle }\end{array}$ & Paclitaxel & $\begin{array}{l}\text { Ovarian } \\
\text { cancer }\end{array}$ & Phase III \\
\hline & NC-4016 & $\begin{array}{l}\text { Polymeric } \\
\text { micelle }\end{array}$ & Oxaliplatin & $\begin{array}{l}\text { Various solid } \\
\text { malignancies }\end{array}$ & Phase I \\
\hline \multirow{3}{*}{$\begin{array}{l}\text { Polym } \\
\text { er-drug } \\
\text { conjug } \\
\text { ate } \\
\text { nanop } \\
\text { articles }\end{array}$} & Oncaspar ${ }^{\circledR}$ & PEG-drug & $\begin{array}{l}\text { L- } \\
\text { asparaginas } \\
\text { e }\end{array}$ & Leukaemia & Market \\
\hline & $\begin{array}{l}\text { PK1 } \\
\text { (FCE28068) }\end{array}$ & HPMA-drug & Doxorubicin & $\begin{array}{l}\text { Breast } \\
\text { cancer, lung } \\
\text { cancer, } \\
\text { colorectal } \\
\text { cancer }\end{array}$ & Phase II \\
\hline & $\begin{array}{l}\text { DOX-OXD } \\
\text { (AD-70) }\end{array}$ & Dextran & Doxorubicin & $\begin{array}{l}\text { Various } \\
\text { malignancies }\end{array}$ & Phase I \\
\hline
\end{tabular}




\section{CHAPTER IV}

\section{CONCLUSION}

The rapid advances in the field of nanomedicine have created a new trend and opened the doors for the development of different tools and strategies for anticancer therapy. Nanoparticle drug formulations have the potential to overcome the limitations of conventional chemotherapy by their ability to selectively target cancer cells over healthy tissue. Properly designed nanoparticles have the ability to accumulate in tumors either by passive or active targeting and enhance the cytotoxic effects of antitumor agents. Several nanoformulations of anticancer drugs are being evaluated in phase II/III clinical trials while relatively few have been approved for clinical use. Nanotechnology provides an opportunity to revisit and reformulate the drugs that have been shelved due to poor oral bioavailability, lack of selectivity to the desired target, or extreme toxicity. Biological nanoparticles, i.e., exosomes, provide another promising avenue for delivery of small and macromolecules. Nevertheless, the field of nanotechnology has the potential to shift the paradigm of treatment for cancer with an ever- growing arsenal of non-targeted and targeted nanomedicines. 


\section{Future perspective}

In spite of various advantages of NPs, efficient delivery of drugs has never been completely achieved due to lack of ideal drug delivery system. The major limitations being low biocompatibility and toxicity. Their characterization, cost, scalability, inability to evade host immune system, limited circulation time and safety issues still remain as a challenge (151). Exosomes seem to overcome several of the limitations associated with the conventional nanoparticles. They have ability to target tissues by utilizing the intrinsic mechanisms of extracellular vesicles. Exosomes are biocompatible, potentially nontoxic, less immunogenic, and provide desired long-term safety for therapeutic use. They have the natural ability to carry nucleic acids and other therapeutic molecules cross membranes that are difficult to cross such as the blood brain barrier (BBB). There are several recent studies published which isolated exosomes from different sources like biological fluids and cell culture media using variety of strategies $(129,142,152)$. However, they still suffer from biocompatibility and scalability issues. Particularly cost-effective, mass-scale production, drug loading and targeting strategies are limitations, which lessen the throughput of this field. More recent development of milk exosomes seem to overcome many of these limitations (126-128, 139). However, immune-compromised subcutaneous xenograft mouse models used in these studies have some limitations as the formulations are not being tested in tumor microenvironment.

Tumor growth is complex and heterogeneous microenvironment consist of different immune cells. So it is crucial to develop nanoformulations that can 
adapt to the microenvironment and improve the selective targeting to tumors. Apart from few, most of the formulations have not yet been in clinic considering this aspect. The studies need to be performed with more sophisticated humanized mouse models (i.e., patient-derived tumor xenograft models) and also in different immunocompetent animal models (such as spontaneous tumor models, carcinogen-mediated tumor models) which take tumor microenvironment into consideration. This will better match the system of human disease and create a wide scope for clinical translatability. 


\section{REFERENCES}

1. Siegel RL, Miller KD, Jemal A. Cancer statistics, 2017. CA: A Cancer Journal for Clinicians. 2017;67(1):7-30.

2. Luo J, Solimini NL, Elledge SJ. Principles of cancer therapy: oncogene and non-oncogene addiction. Cell. 2009;136(5):823-37.

3. Hanahan D, Weinberg RA. The hallmarks of cancer. Cell. 2000;100(1):57-70.

4. Sikora K. The impact of future technology on cancer care. Clinical medicine (London, England). 2002;2(6):560-8.

5. Park JH, von Maltzahn G, Xu MJ, Fogal V, Kotamraju VR, Ruoslahti E, et al. Cooperative nanomaterial system to sensitize, target, and treat tumors. Proceedings of the National Academy of Sciences of the United States of America. 2010;107(3):981-6.

6. Reinbolt RE, Patel R, Pan X, Timmers CD, Pilarski R, Shapiro CL, et al. Risk factors for anthracycline-associated cardiotoxicity. Supportive care in cancer : official journal of the Multinational Association of Supportive Care in Cancer. 2016;24(5):2173-80.

7. Strebhardt K, Ullrich A. Paul Ehrlich's magic bullet concept: 100 years of progress. Nature reviews Cancer. 2008;8(6):473-80.

8. Torchilin VP. Drug targeting. European journal of pharmaceutical sciences : official journal of the European Federation for Pharmaceutical Sciences. 2000;11 Suppl 2:S81-91.

9. Sakamoto JH, van de Ven AL, Godin B, Blanco E, Serda RE, Grattoni A, et al. Enabling individualized therapy through nanotechnology. Pharmacological research. 2010;62(2):57-89.

10. Chidambaram M, Manavalan R, Kathiresan K. Nanotherapeutics to overcome conventional cancer chemotherapy limitations. Journal of pharmacy \& pharmaceutical sciences : a publication of the Canadian Society for Pharmaceutical Sciences, Societe canadienne des sciences pharmaceutiques. 2011;14(1):67-77. 
11. Shaffer C. Nanomedicine transforms drug delivery. Drug discovery today. 2005;10(23-24):1581-2.

12. Moghimi SM, Hunter AC, Murray JC. Nanomedicine: current status and future prospects. FASEB journal : official publication of the Federation of American Societies for Experimental Biology. 2005;19(3):311-30.

13. Sahoo SK, Parveen S, Panda JJ. The present and future of nanotechnology in human health care. Nanomedicine : nanotechnology, biology, and medicine. 2007;3(1):20-31.

14. Sahoo SK, Labhasetwar V. Nanotech approaches to drug delivery and imaging. Drug discovery today. 2003;8(24):1112-20.

15. Davis ME, Chen ZG, Shin DM. Nanoparticle therapeutics: an emerging treatment modality for cancer. Nature reviews Drug discovery. 2008;7(9):77182.

16. Allen TM, Cullis PR. Drug delivery systems: entering the mainstream. Science (New York, NY). 2004;303(5665):1818-22.

17. Bae KH, Chung HJ, Park TG. Nanomaterials for cancer therapy and imaging. Molecules and cells. 2011;31(4):295-302.

18. Muthu MS, Kutty RV, Luo Z, Xie J, Feng SS. Theranostic vitamin E TPGS micelles of transferrin conjugation for targeted co-delivery of docetaxel and ultra bright gold nanoclusters. Biomaterials. 2015;39:234-48.

19. Kim SS, Rait A, Kim E, DeMarco J, Pirollo KF, Chang EH. Encapsulation of temozolomide in a tumor-targeting nanocomplex enhances anti-cancer efficacy and reduces toxicity in a mouse model of glioblastoma. Cancer letters. 2015;369(1):250-8.

20. Kesavan A, Ilaiyaraja P, Sofi Beaula W, Veena Kumari V, Sugin Lal J, Arunkumar $\mathrm{C}$, et al. Tumor targeting using polyamidoamine dendrimer-cisplatin nanoparticles functionalized with diglycolamic acid and herceptin. European journal of pharmaceutics and biopharmaceutics : official journal of Arbeitsgemeinschaft fur Pharmazeutische Verfahrenstechnik eV. 2015;96:25563.

21. Jain A, Jain A, Garg NK, Tyagi RK, Singh B, Katare OP, et al. Surface engineered polymeric nanocarriers mediate the delivery of transferrinmethotrexate conjugates for an improved understanding of brain cancer. Acta biomaterialia. 2015;24:140-51.

22. Chen HH, Huang WC, Chiang WH, Liu TI, Shen MY, Hsu YH, et al. pHResponsive therapeutic solid lipid nanoparticles for reducing P-glycoproteinmediated drug efflux of multidrug resistant cancer cells. International journal of nanomedicine. 2015;10:5035-48. 
23. Nahar M, Dutta T, Murugesan S, Asthana A, Mishra D, Rajkumar V, et al. Functional polymeric nanoparticles: an efficient and promising tool for active delivery of bioactives. Critical reviews in therapeutic drug carrier systems. 2006;23(4):259-318.

24. Johnson SM, Bangham AD. Potassium permeability of single compartment liposomes with and without valinomycin. Biochimica et Biophysica Acta (BBA) - Biomembranes. 1969;193(1):82-91.

25. Akbarzadeh A, Rezaei-Sadabady R, Davaran S, Joo SW, Zarghami N, Hanifehpour Y, et al. Liposome: classification, preparation, and applications. Nanoscale Research Letters. 2013;8(1):102.

26. $\mathrm{Xu} \mathrm{W}$, Ling $\mathrm{P}$, Zhang $\mathrm{T}$. Polymeric micelles, a promising drug delivery system to enhance bioavailability of poorly water-soluble drugs. Journal of drug delivery. 2013;2013:340315.

27. Tomalia DA, Baker H, Dewald J, Hall M, Kallos G, Martin S, et al. A New Class of Polymers: Starburst-Dendritic Macromolecules. Polym J. 1985;17(1):117-32.

28. Abbasi E, Aval SF, Akbarzadeh A, Milani M, Nasrabadi HT, Joo SW, et al. Dendrimers: synthesis, applications, and properties. Nanoscale Research Letters. 2014;9(1):247.

29. Karra N, Benita S. The ligand nanoparticle conjugation approach for targeted cancer therapy. Current drug metabolism. 2012;13(1):22-41.

30. Langer R, Folkman J. Polymers for the sustained release of proteins and other macromolecules. Nature. 1976;263(5580):797-800.

31. Musyanovych A, Landfester K. Polymer micro- and nanocapsules as biological carriers with multifunctional properties. Macromolecular bioscience. 2014;14(4):458-77.

32. Lambert G, Fattal E, Couvreur P. Nanoparticulate systems for the delivery of antisense oligonucleotides. Advanced drug delivery reviews. 2001;47(1):99-112.

33. Vasir JK, Labhasetwar V. Biodegradable nanoparticles for cytosolic delivery of therapeutics. Advanced drug delivery reviews. 2007;59(8):718-28.

34. Olivier JC. Drug transport to brain with targeted nanoparticles. NeuroRx : the journal of the American Society for Experimental NeuroTherapeutics. 2005;2(1):108-19.

35. Huh MS, Lee SY, Park S, Lee S, Chung H, Lee S, et al. Tumor-homing glycol chitosan/polyethylenimine nanoparticles for the systemic delivery of siRNA in tumor-bearing mice. Journal of controlled release : official journal of the Controlled Release Society. 2010;144(2):134-43. 
36. Gan CW, Feng SS. Transferrin-conjugated nanoparticles of poly(lactide)D-alpha-tocopheryl polyethylene glycol succinate diblock copolymer for targeted drug delivery across the blood-brain barrier. Biomaterials. 2010;31(30):7748-57.

37. Azzi J, Tang L, Moore R, Tong R, El Haddad N, Akiyoshi T, et al. Polylactide-cyclosporin A nanoparticles for targeted immunosuppression. FASEB journal : official publication of the Federation of American Societies for Experimental Biology. 2010;24(10):3927-38.

38. Avgoustakis K. Pegylated poly(lactide) and poly(lactide-co-glycolide) nanoparticles: preparation, properties and possible applications in drug delivery. Current drug delivery. 2004;1(4):321-33.

39. Derakhshandeh K, Azandaryani AH. Active-targeted Nanotherapy as Smart Cancer Treatment. In: Sezer AD, editor. Smart Drug Delivery System. Rijeka: InTech; 2016. p. Ch. 04.

40. Gharatape A, Salehi R. Recent progress in theranostic applications of hybrid gold nanoparticles. European journal of medicinal chemistry. 2017;138:221-33.

41. Bamrungsap $\mathrm{S}$, Zhao $\mathrm{Z}$, Chen $\mathrm{T}$, Wang $\mathrm{L}$, Li C, Fu T, et al. Nanotechnology in therapeutics: a focus on nanoparticles as a drug delivery system. Nanomedicine (London, England). 2012;7(8):1253-71.

42. Maeda $\mathrm{H}$. The enhanced permeability and retention (EPR) effect in tumor vasculature: the key role of tumor-selective macromolecular drug targeting. Advances in enzyme regulation. 2001;41:189-207.

43. Jain RK. Delivery of molecular and cellular medicine to solid tumors. Advanced drug delivery reviews. 2001;46(1-3):149-68.

44. Jain RK, Stylianopoulos T. Delivering nanomedicine to solid tumors. Nature reviews Clinical oncology. 2010;7(11):653-64.

45. Hatakeyama $\mathrm{H}$, Akita $\mathrm{H}$, Harashima $\mathrm{H}$. A multifunctional envelope type nano device (MEND) for gene delivery to tumours based on the EPR effect: a strategy for overcoming the PEG dilemma. Advanced drug delivery reviews. 2011;63(3):152-60.

46. Knop K, Hoogenboom R, Fischer D, Schubert US. Poly(ethylene glycol) in drug delivery: pros and cons as well as potential alternatives. Angewandte Chemie (International ed in English). 2010;49(36):6288-308.

47. Alexis F, Pridgen E, Molnar LK, Farokhzad OC. Factors affecting the clearance and biodistribution of polymeric nanoparticles. Molecular pharmaceutics. 2008;5(4):505-15.

48. Ruoslahti E, Bhatia SN, Sailor MJ. Targeting of drugs and nanoparticles to tumors. The Journal of cell biology. 2010;188(6):759-68. 
49. Srinivasarao M, Galliford CV, Low PS. Principles in the design of ligandtargeted cancer therapeutics and imaging agents. Nature reviews Drug discovery. 2015;14(3):203-19.

50. Parveen S, Misra R, Sahoo SK. Nanoparticles: a boon to drug delivery, therapeutics, diagnostics and imaging. Nanomedicine : nanotechnology, biology, and medicine. 2012;8(2):147-66.

51. Kirpotin DB, Drummond DC, Shao Y, Shalaby MR, Hong K, Nielsen UB, et al. Antibody targeting of long-circulating lipidic nanoparticles does not increase tumor localization but does increase internalization in animal models. Cancer research. 2006;66(13):6732-40.

52. Bertrand $\mathrm{N}, \mathrm{Wu} \mathrm{J}, \mathrm{Xu} \mathrm{X}$, Kamaly $\mathrm{N}$, Farokhzad OC. Cancer nanotechnology: the impact of passive and active targeting in the era of modern cancer biology. Advanced drug delivery reviews. 2014;66:2-25.

53. Warenius H, Galfre G, Bleehen N, Milstein C. Attempted targeting of a monoclonal antibody in a human tumour xenograft system. European Journal of Cancer and Clinical Oncology. 1981;17(9):1009-15.

54. Chames P, Van Regenmortel M, Weiss E, Baty D. Therapeutic antibodies: successes, limitations and hopes for the future. British journal of pharmacology. 2009;157(2):220-33.

55. Clynes RA, Towers TL, Presta LG, Ravetch JV. Inhibitory Fc receptors modulate in vivo cytotoxicity against tumor targets. Nature medicine. 2000;6(4):443-6.

56. Gabizon AA. Pegylated liposomal doxorubicin: metamorphosis of an old drug into a new form of chemotherapy. Cancer investigation. 2001;19(4):424-36.

57. James J, Dubs G. FDA approves new kind of lymphoma treatment. Food and Drug Administration. AIDS treatment news. 1997(284):2.

58. Albanell J, Baselga J. Trastuzumab, a humanized anti-HER2 monoclonal antibody, for the treatment of breast cancer. Drugs Today (Barc). 1999;35(12):931-46.

59. Ferrara N. VEGF as a therapeutic target in cancer. Oncology. 2005;69(Suppl. 3):11-6.

60. Carter P. Improving the efficacy of antibody-based cancer therapies. Nature Reviews Cancer. 2001;1(2):118-29.

61. Orava EW, Cicmil N, Gariepy J. Delivering cargoes into cancer cells using DNA aptamers targeting internalized surface portals. Biochimica et biophysica acta. 2010;1798(12):2190-200.

62. White RR, Sullenger BA, Rusconi CP. Developing aptamers into therapeutics. Journal of Clinical Investigation. 2000;106(8):929. 
63. Farokhzad OC, Cheng J, Teply BA, Sherifi I, Jon S, Kantoff PW, et al. Targeted nanoparticle-aptamer bioconjugates for cancer chemotherapy in vivo. Proceedings of the National Academy of Sciences. 2006;103(16):6315-20.

64. An Y, Wu J, Yang B, Zhu Z, Gao M, Yu C, et al. Selection and Application of DNA Aptamer Against Oncogene Amplified in Breast Cancer 1. Journal of molecular evolution. 2015;81(5-6):179-85.

65. Lee SK, Park MW, Yang EG, Yu J, Jeong S. An RNA aptamer that binds to the beta-catenin interaction domain of TCF-1 protein. Biochemical and biophysical research communications. 2005;327(1):294-9.

66. Lee HK, Choi YS, Park YA, Jeong S. Modulation of oncogenic transcription and alternative splicing by beta-catenin and an RNA aptamer in colon cancer cells. Cancer research. 2006;66(21):10560-6.

67. Bardeesy N, Pelletier J. Overlapping RNA and DNA binding domains of the wt1 tumor suppressor gene product. Nucleic acids research. 1998;26(7):1784-92.

68. Roy K, Kanwar RK, Kanwar JR. LNA aptamer based multi-modal, Fe3O4saturated lactoferrin (Fe3O4-bLf) nanocarriers for triple positive (EpCAM, CD133, CD44) colon tumor targeting and NIR, MRI and CT imaging. Biomaterials. 2015;71:84-99.

69. Tuerk C, Gold L. Systematic evolution of ligands by exponential enrichment: RNA ligands to bacteriophage T4 DNA polymerase. Science (New York, NY). 1990;249(4968):505-10.

70. Farokhzad OC, Cheng J, Teply BA, Sherifi I, Jon S, Kantoff PW, et al. Targeted nanoparticle-aptamer bioconjugates for cancer chemotherapy in vivo. Proceedings of the National Academy of Sciences of the United States of America. 2006;103(16):6315-20.

71. Ellington $A D$, Szostak JW. In vitro selection of RNA molecules that bind specific ligands. Nature. 1990;346(6287):818-22.

72. Chou LY, Ming K, Chan WC. Strategies for the intracellular delivery of nanoparticles. Chemical Society reviews. 2011;40(1):233-45.

73. Daniels TR, Bernabeu E, Rodriguez JA, Patel S, Kozman M, Chiappetta $\mathrm{DA}$, et al. The transferrin receptor and the targeted delivery of therapeutic agents against cancer. Biochimica et biophysica acta. 2012;1820(3):291-317.

74. Choi $\mathrm{CH}$, Alabi CA, Webster P, Davis ME. Mechanism of active targeting in solid tumors with transferrin-containing gold nanoparticles. Proceedings of the National Academy of Sciences of the United States of America. 2010;107(3):1235-40.

75. Krishna AD, Mandraju RK, Kishore G, Kondapi AK. An efficient targeted drug delivery through apotransferrin loaded nanoparticles. PloS one. 2009;4(10):e7240. 
76. Brissette R, Prendergast JK, Goldstein NI. Identification of cancer targets and therapeutics using phage display. Current opinion in drug discovery \& development. 2006;9(3):363-9.

77. Wang $\mathrm{C}$, Wang $\mathrm{X}$, Zhong $\mathrm{T}$, Zhao $\mathrm{Y}$, Zhang $\mathrm{WQ}$, Ren $\mathrm{W}$, et al. The antitumor activity of tumor-homing peptide-modified thermosensitive liposomes containing doxorubicin on MCF-7/ADR: in vitro and in vivo. International journal of nanomedicine. 2015;10:2229-48.

78. Shu D, Li H, Shu Y, Xiong G, Carson WE, 3rd, Haque F, et al. Systemic Delivery of Anti-miRNA for Suppression of Triple Negative Breast Cancer Utilizing RNA Nanotechnology. ACS nano. 2015;9(10):9731-40.

79. Passarella RJ, Spratt DE, van der Ende AE, Phillips JG, Wu H, Sathiyakumar V, et al. Targeted nanoparticles that deliver a sustained, specific release of Paclitaxel to irradiated tumors. Cancer research. 2010;70(11):4550-9.

80. Mandelin J, Cardo-Vila M, Driessen WH, Mathew P, Navone NM, Lin SH, et al. Selection and identification of ligand peptides targeting a model of castrate-resistant osteogenic prostate cancer and their receptors. Proceedings of the National Academy of Sciences of the United States of America. 2015;112(12):3776-81.

81. Pasqualini R, Millikan RE, Christianson DR, Cardo-Vila M, Driessen WH, Giordano RJ, et al. Targeting the interleukin-11 receptor alpha in metastatic prostate cancer: A first-in-man study. Cancer. 2015;121(14):2411-21.

82. Danhier F, Pourcelle V, Marchand-Brynaert J, Jerome C, Feron O, Preat V. Targeting of tumor endothelium by RGD-grafted PLGA-nanoparticles. Methods in enzymology. 2012;508:157-75.

83. Toti US, Guru BR, Grill AE, Panyam J. Interfacial activity assisted surface functionalization: a novel approach to incorporate maleimide functional groups and CRGD peptide on polymeric nanoparticles for targeted drug delivery. Molecular pharmaceutics. 2010;7(4):1108-17.

84. Subedi M, Minn I, Chen J, Kim Y, Ok K, Jung YW, et al. Design, synthesis and biological evaluation of PSMA/hepsin-targeted heterobivalent ligands. European journal of medicinal chemistry. 2016;118:208-18.

85. Chandran SS, Banerjee SR, Mease RC, Pomper MG, Denmeade SR. Characterization of a targeted nanoparticle functionalized with a urea-based inhibitor of prostate-specific membrane antigen (PSMA). Cancer biology \& therapy. 2008;7(6):974-82.

86. Von Hoff DD, Mita MM, Ramanathan RK, Weiss GJ, Mita AC, LoRusso PM, et al. Phase I Study of PSMA-Targeted Docetaxel-Containing Nanoparticle BIND-014 in Patients with Advanced Solid Tumors. Clinical cancer research : an official journal of the American Association for Cancer Research. 2016;22(13):3157-63. 
87. Vasir JK, Labhasetwar V. Targeted drug delivery in cancer therapy. Technology in cancer research \& treatment. 2005;4(4):363-74.

88. Talekar M, Kendall J, Denny W, Garg S. Targeting of nanoparticles in cancer: drug delivery and diagnostics. Anti-cancer drugs. 2011;22(10):949-62.

89. Reddy JA, Westrick E, Vlahov I, Howard SJ, Santhapuram HK, Leamon $\mathrm{CP}$. Folate receptor specific anti-tumor activity of folate-mitomycin conjugates. Cancer chemotherapy and pharmacology. 2006;58(2):229-36.

90. Lu Y, Low PS. Folate-mediated delivery of macromolecular anticancer therapeutic agents. Advanced drug delivery reviews. 2002;54(5):675-93.

91. Antony AC. Folate receptors. Annual review of nutrition. 1996;16:501-21.

92. Liang C, Yang Y, Ling Y, Huang Y, Li T, Li X. Improved therapeutic effect of folate-decorated PLGA-PEG nanoparticles for endometrial carcinoma. Bioorganic \& medicinal chemistry. 2011;19(13):4057-66.

93. Zheng M, Gong P, Zheng C, Zhao P, Luo Z, Ma Y, et al. Lipid-Polymer Nanoparticles for Folate-Receptor Targeting Delivery of Doxorubicin. Journal of nanoscience and nanotechnology. 2015;15(7):4792-8.

94. Wang F, Chen Y, Zhang D, Zhang Q, Zheng D, Hao L, et al. Folatemediated targeted and intracellular delivery of paclitaxel using a novel deoxycholic acid-O-carboxymethylated chitosan-folic acid micelles. International journal of nanomedicine. 2012;7:325-37.

95. Kang JH, Battogtokh G, Ko YT. Folate-targeted liposome encapsulating chitosan/oligonucleotide polyplexes for tumor targeting. AAPS PharmSciTech. 2014;15(5):1087-92.

96. Chen L, Liu Y, Wang W, Liu K. Effect of integrin receptor-targeted liposomal paclitaxel for hepatocellular carcinoma targeting and therapy. Oncology letters. 2015;10(1):77-84.

97. Zheng $\mathrm{Y}, \mathrm{Yu} \mathrm{B}$, Weecharangsan $\mathrm{W}$, Piao L, Darby M, Mao $\mathrm{Y}$, et al. Transferrin-conjugated lipid-coated PLGA nanoparticles for targeted delivery of aromatase inhibitor 7alpha-APTADD to breast cancer cells. International journal of pharmaceutics. 2010;390(2):234-41.

98. Gao J, Xia Y, Chen H, Yu Y, Song J, Li W, et al. Polymer-lipid hybrid nanoparticles conjugated with anti-EGF receptor antibody for targeted drug delivery to hepatocellular carcinoma. Nanomedicine (London, England). 2014;9(2):279-93.

99. Liu P, Li Z, Zhu M, Sun Y, Li Y, Wang H, et al. Preparation of EGFR monoclonal antibody conjugated nanoparticles and targeting to hepatocellular carcinoma. Journal of materials science Materials in medicine. 2010;21(2):5516. 
100. Delac $M$, Motaln $H$, Ulrich $H$, Lah TT. Aptamer for imaging and therapeutic targeting of brain tumor glioblastoma. Cytometry Part A : the journal of the International Society for Analytical Cytology. 2015;87(9):806-16.

101. Jiang J, Chen $\mathrm{H}, \mathrm{Yu} \mathrm{C}$, Zhang $\mathrm{Y}$, Chen M, Tian S, et al. The promotion of salinomycin delivery to hepatocellular carcinoma cells through EGFR and CD133 aptamers conjugation by PLGA nanoparticles. Nanomedicine (London, England). 2015;10(12):1863-79.

102. Jolck RI, Feldborg LN, Andersen S, Moghimi SM, Andresen TL. Engineering liposomes and nanoparticles for biological targeting. Advances in biochemical engineering/biotechnology. 2011;125:251-80.

103. Conde J, Dias JT, Grazu V, Moros M, Baptista PV, de la Fuente JM. Revisiting 30 years of biofunctionalization and surface chemistry of inorganic nanoparticles for nanomedicine. Frontiers in chemistry. 2014;2:48.

104. Nobs L, Buchegger F, Gurny R, Allemann E. Biodegradable nanoparticles for direct or two-step tumor immunotargeting. Bioconjugate chemistry. 2006;17(1):139-45.

105. Kocbek P, Obermajer N, Cegnar M, Kos J, Kristl J. Targeting cancer cells using PLGA nanoparticles surface modified with monoclonal antibody. Journal of controlled release : official journal of the Controlled Release Society. 2007;120(1-2):18-26.

106. Acharya S, Dilnawaz F, Sahoo SK. Targeted epidermal growth factor receptor nanoparticle bioconjugates for breast cancer therapy. Biomaterials. 2009;30(29):5737-50.

107. Sudhan Shaik M, Kanikkannan N, Singh M. Conjugation of anti-My9 antibody to stealth monensin liposomes and the effect of conjugated liposomes on the cytotoxicity of immunotoxin. Journal of controlled release : official journal of the Controlled Release Society. 2001;76(3):285-95.

108. Ulbrich K, Hekmatara T, Herbert E, Kreuter J. Transferrin- and transferrinreceptor-antibody-modified nanoparticles enable drug delivery across the bloodbrain barrier (BBB). European journal of pharmaceutics and biopharmaceutics : official journal of Arbeitsgemeinschaft fur Pharmazeutische Verfahrenstechnik eV. 2009;71(2):251-6.

109. Hiller Y, Gershoni JM, Bayer EA, Wilchek M. Biotin binding to avidin. Oligosaccharide side chain not required for ligand association. The Biochemical journal. 1987;248(1):167-71.

110. Green NM. Avidin and streptavidin. Methods in enzymology. 1990;184:51-67.

111. Kawato T, Mizohata E, Shimizu Y, Meshizuka T, Yamamoto T, Takasu N, et al. Structure-based design of a streptavidin mutant specific for an artificial biotin analogue. Journal of biochemistry. 2015;157(6):467-75. 
112. Kolb HC, Finn MG, Sharpless KB. Click Chemistry: Diverse Chemical Function from a Few Good Reactions. Angewandte Chemie (International ed in English). 2001;40(11):2004-21.

113. Marques-Gallego P, de Kroon Al. Ligation strategies for targeting liposomal nanocarriers. BioMed research international. 2014;2014:129458.

114. Baskin JM, Prescher JA, Laughlin ST, Agard NJ, Chang PV, Miller IA, et al. Copper-free click chemistry for dynamic in vivo imaging. Proceedings of the National Academy of Sciences of the United States of America. 2007;104(43):16793-7.

115. Koo H, Lee S, Na JH, Kim SH, Hahn SK, Choi K, et al. Bioorthogonal copper-free click chemistry in vivo for tumor-targeted delivery of nanoparticles. Angewandte Chemie (International ed in English). 2012;51(47):11836-40.

116. Witwer KW, Buzas El, Bemis LT, Bora A, Lasser C, Lotvall J, et al. Standardization of sample collection, isolation and analysis methods in extracellular vesicle research. Journal of extracellular vesicles. 2013;2.

117. Vlassov AV, Magdaleno S, Setterquist R, Conrad R. Exosomes: current knowledge of their composition, biological functions, and diagnostic and therapeutic potentials. Biochimica et biophysica acta. 2012;1820(7):940-8.

118. S ELA, Mager I, Breakefield XO, Wood MJ. Extracellular vesicles: biology and emerging therapeutic opportunities. Nature reviews Drug discovery. 2013;12(5):347-57.

119. Jia S, Zocco D, Samuels ML, Chou MF, Chammas R, Skog J, et al. Emerging technologies in extracellular vesicle-based molecular diagnostics. Expert review of molecular diagnostics. 2014;14(3):307-21.

120. van Dommelen SM, Vader P, Lakhal S, Kooijmans SA, van Solinge WW, Wood MJ, et al. Microvesicles and exosomes: opportunities for cell-derived membrane vesicles in drug delivery. Journal of controlled release : official journal of the Controlled Release Society. 2012;161(2):635-44.

121. Vader $P$, Breakefield XO, Wood MJ. Extracellular vesicles: emerging targets for cancer therapy. Trends in molecular medicine. 2014;20(7):385-93.

122. Kooijmans $S A$, Vader $P$, van Dommelen $S M$, van Solinge WW, Schiffelers RM. Exosome mimetics: a novel class of drug delivery systems. International journal of nanomedicine. 2012;7:1525-41.

123. Lakhal S, Wood MJ. Exosome nanotechnology: an emerging paradigm shift in drug delivery: exploitation of exosome nanovesicles for systemic in vivo delivery of RNAi heralds new horizons for drug delivery across biological barriers. BioEssays : news and reviews in molecular, cellular and developmental biology. 2011;33(10):737-41. 
124. Shahabipour F, Barati N, Johnston TP, Derosa G, Maffioli P, Sahebkar A. Exosomes: Nanoparticulate tools for RNA interference and drug delivery. Journal of cellular physiology. 2017;232(7):1660-8.

125. Kamerkar S, LeBleu VS, Sugimoto H, Yang S, Ruivo CF, Melo SA, et al. Exosomes facilitate therapeutic targeting of oncogenic KRAS in pancreatic cancer. Nature. 2017;546(7659):498-503.

126. Munagala R, Aqil F, Jeyabalan J, Gupta RC. Bovine milk-derived exosomes for drug delivery. Cancer letters. 2016;371(1):48-61.

127. Aqil F, Kausar H, Agrawal AK, Jeyabalan J, Kyakulaga AH, Munagala R, et al. Exosomal formulation enhances therapeutic response of celastrol against lung cancer. Experimental and molecular pathology. 2016;101(1):12-21.

128. Agrawal AK, Aqil F, Jeyabalan J, Spencer WA, Beck J, Gachuki BW, et al. Milk-derived exosomes for oral delivery of paclitaxel. Nanomedicine : nanotechnology, biology, and medicine. 2017;13(5):1627-36.

129. Tian Y, Li S, Song J, Ji T, Zhu M, Anderson GJ, et al. A doxorubicin delivery platform using engineered natural membrane vesicle exosomes for targeted tumor therapy. Biomaterials. 2014;35(7):2383-90.

130. Hadla M, Palazzolo S, Corona G, Caligiuri I, Canzonieri V, Toffoli G, et al. Exosomes increase the therapeutic index of doxorubicin in breast and ovarian cancer mouse models. Nanomedicine (London, England). 2016;11(18):2431-41.

131. Saari H, Lazaro-Ibanez E, Viitala T, Vuorimaa-Laukkanen E, Siljander P, Yliperttula M. Microvesicle- and exosome-mediated drug delivery enhances the cytotoxicity of Paclitaxel in autologous prostate cancer cells. Journal of controlled release : official journal of the Controlled Release Society. 2015;220(Pt B):727-37.

132. Kim MS, Haney MJ, Zhao Y, Mahajan V, Deygen I, Klyachko NL, et al. Development of exosome-encapsulated paclitaxel to overcome MDR in cancer cells. Nanomedicine : nanotechnology, biology, and medicine. 2016;12(3):65564.

133. Lou G, Song X, Yang F, Wu S, Wang J, Chen Z, et al. Exosomes derived from miR-122-modified adipose tissue-derived MSCs increase chemosensitivity of hepatocellular carcinoma. Journal of hematology \& oncology. 2015;8:122.

134. Shimbo K, Miyaki S, Ishitobi H, Kato $\mathrm{Y}$, Kubo T, Shimose S, et al. Exosome-formed synthetic microRNA-143 is transferred to osteosarcoma cells and inhibits their migration. Biochemical and biophysical research communications. 2014;445(2):381-7.

135. Lunavat TR, Jang SC, Nilsson L, Park HT, Repiska G, Lasser C, et al. RNAi delivery by exosome-mimetic nanovesicles - Implications for targeting CMyc in cancer. Biomaterials. 2016;102:231-8. 
136. Greco KA, Franzen CA, Foreman KE, Flanigan RC, Kuo PC, Gupta GN. PLK-1 Silencing in Bladder Cancer by siRNA Delivered With Exosomes. Urology. 2016;91:241.e1-7.

137. Sun D, Zhuang X, Xiang X, Liu Y, Zhang S, Liu C, et al. A novel nanoparticle drug delivery system: the anti-inflammatory activity of curcumin is enhanced when encapsulated in exosomes. Molecular therapy : the journal of the American Society of Gene Therapy. 2010;18(9):1606-14.

138. Srivastava A, Amreddy N, Babu A, Panneerselvam J, Mehta M, Muralidharan R, et al. Nanosomes carrying doxorubicin exhibit potent anticancer activity against human lung cancer cells. Scientific reports. 2016;6:38541.

139. Munagala R, Aqil F, Jeyabalan J, Agrawal AK, Mudd AM, Kyakulaga AH, et al. Exosomal formulation of anthocyanidins against multiple cancer types. Cancer letters. 2017;393:94-102.

140. Ohno SI, Takanashi M, Sudo K, Ueda S, Ishikawa A, Matsuyama N, et al. Systemically Injected Exosomes Targeted to EGFR Deliver Antitumor MicroRNA to Breast Cancer Cells. Molecular therapy : the journal of the American Society of Gene Therapy. 2013;21(1):185-91.

141. El-Andaloussi S, Lee Y, Lakhal-Littleton S, Li J, Seow Y, Gardiner C, et al. Exosome-mediated delivery of siRNA in vitro and in vivo. Nature protocols. 2012;7(12):2112-26.

142. Alvarez-Erviti L, Seow Y, Yin H, Betts C, Lakhal S, Wood MJ. Delivery of siRNA to the mouse brain by systemic injection of targeted exosomes. Nature biotechnology. 2011;29(4):341-5.

143. Kooijmans SA, Aleza CG, Roffler SR, van Solinge WW, Vader P, Schiffelers RM. Display of GPI-anchored anti-EGFR nanobodies on extracellular vesicles promotes tumour cell targeting. Journal of extracellular vesicles. 2016;5:31053.

144. Smyth T, Petrova K, Payton NM, Persaud I, Redzic JS, Graner MW, et al. Surface functionalization of exosomes using click chemistry. Bioconjugate chemistry. 2014;25(10):1777-84.

145. Matsumura Y, Gotoh M, Muro K, Yamada Y, Shirao K, Shimada Y, et al. Phase I and pharmacokinetic study of MCC-465, a doxorubicin (DXR) encapsulated in PEG immunoliposome, in patients with metastatic stomach cancer. Annals of oncology : official journal of the European Society for Medical Oncology. 2004;15(3):517-25.

146. Mamot C, Ritschard R, Wicki A, Stehle G, Dieterle T, Bubendorf L, et al. Tolerability, safety, pharmacokinetics, and efficacy of doxorubicin-loaded antiEGFR immunoliposomes in advanced solid tumours: a phase 1 dose-escalation study. The Lancet Oncology. 2012;13(12):1234-41. 
147. Pirollo KF, Nemunaitis J, Leung PK, Nunan R, Adams J, Chang EH. Safety and Efficacy in Advanced Solid Tumors of a Targeted Nanocomplex Carrying the p53 Gene Used in Combination with Docetaxel: A Phase 1b Study. Molecular therapy : the journal of the American Society of Gene Therapy. 2016;24(9):1697-706.

148. Davis ME. The first targeted delivery of siRNA in humans via a selfassembling, cyclodextrin polymer-based nanoparticle: from concept to clinic. Molecular pharmaceutics. 2009;6(3):659-68.

149. May JP, Li SD. Hyperthermia-induced drug targeting. Expert opinion on drug delivery. 2013;10(4):511-27.

150. Matsumura Y, Hamaguchi T, Ura T, Muro K, Yamada Y, Shimada Y, et al. Phase I clinical trial and pharmacokinetic evaluation of NK911, a micelleencapsulated doxorubicin. British journal of cancer. 2004;91(10):1775-81.

151. Wicki A, Witzigmann D, Balasubramanian V, Huwyler J. Nanomedicine in cancer therapy: Challenges, opportunities, and clinical applications. Journal of Controlled Release. 2015;200:138-57.

152. Wolfers J, Lozier A, Raposo G, Regnault A, Thery C, Masurier C, et al. Tumor-derived exosomes are a source of shared tumor rejection antigens for CTL cross-priming. Nature medicine. 2001;7(3):297-303.

153. ClinicalTrials.gov. Study of MBP-426 in patients with second line gastric, gastroesophageal, or esophageal adenocarcinoma. Available from: http://clinicaltrials.gov/show/NCT00964080. Accessed November 5, 2013.

154. ClinicalTrials.gov. Safety study of infusion of SGT-53 to treat solid tumors. Available from: http://clinicaltrials.gov/show/ NCT00470613. Accessed November 5, 2013.

155. ClinicalTrials.gov. Safety study of CALAA-01 to treat solid tumor cancers. Available from: http://clinicaltrials.gov/show/NCT00689065. Accessed November 5, 2013.

156. ClinicalTrials.gov. A Phase 2 study to determine the safety and efficacy of BIND-014 (docetaxel nanoparticles injectable suspension) as second line therapy to patients with non-small cell lung cancer. Available from: http://clinicaltrials.gov/show/NCT01792479. Accessed November 5, 2013.

157. Clinical Trials.gov. A Phase I trial of nanoliposomal CPT-11 (NL CPT 11) in patients with recurrent high-grade gliomas. Available from: http://clinicaltrials.gov/show/NCT00734682. Accessed November 5, 2013.

158. ClinicalTrials.gov A Phase 2 study to determine the safety and efficacy of BIND-014 (docetaxel nanoparticles injectable suspension) as second line therapy to patients with non-small cell lung cancer. [Accessed November 5 , 2013]. Available from: http://clinicaltrials.gov/show/NCT01792479. 


\section{CURRICULAM VITAE}

Divya Karukonda

Divya.Karukonda@louisville.edu,

Ph No: 9163072125

\section{Education}

Graduate Student

2015 - Present

Department of Pharmacology and Toxicology

University of Louisville, Kentucky

Masters in Pharmaceutical Sciences

2012 - 2014

Jawaharlal Nehru Technological University, India

Bachelor of Science in Pharmacy

2008 - 2012

Rajiv Gandhi University of Health sciences, India

\section{Awards and Honors}

IPIBS Integrated Programs in Biomedical Sciences (IPIBS); 2015-2017

Fellowship award, University of Louisville, Kentucky

Best intern student - Dr.Reddy's Pharmaceutical Industry, Hyderabad, India Summer- 2013 
Best player of the chess tournament

National level round 3- 2007

Award from Ministry of State of Andhra Pradesh as player of the tournament 2005

\section{Abstracts}

Milk-derived exosomes - a platform nanocarrier to enhance anti-proliferative, anti-inflammatory and anti-cancer activities of small drug molecules against multiple human cancers Ramesh C. Gupta, Farrukh Aqil, Manicka V. Vadhanam, , Jeyaprakash Jeyabalan, Ashish K. Agrawal, Ashley M. Mudd, Alhassan Kyakulaga, Divya Karukonda, Wendy Spencer and Radha Munagala

\section{Conferences and Workshops}

Attended National Poster Symposium on Organic/ Medicinal Chemistry as a delegate, conducted by Royal Society of Chemistry (London)-Deccan section (India) at IICT, Hyderabad, India.

Workshop on innovation in life sciences (Sept 2011) Bangalore, India.

3rd World Congress on Biotechnology (Sept 2012) Hyderabad, India.

\section{Paper Presentations}

Presented a paper on "Drug Discovery and Development Process" in DRAVYAKA'11, a National level seminar held at Geethanjali College of Pharmacy, Hyderabad

Presented a paper on "Pharmaceutical Engineering" in j-TALENT'10, a National contest on "Emerging Technologies" held at Jyothishmathi College of Pharmacy, Hyderabad

\section{Motto of Life:}

"Everyone in this world is born to accomplish a specific task. Forget about the failures, instead search for the true purpose of your existence"

- Dr. A.P.J. Abdul Kalam 